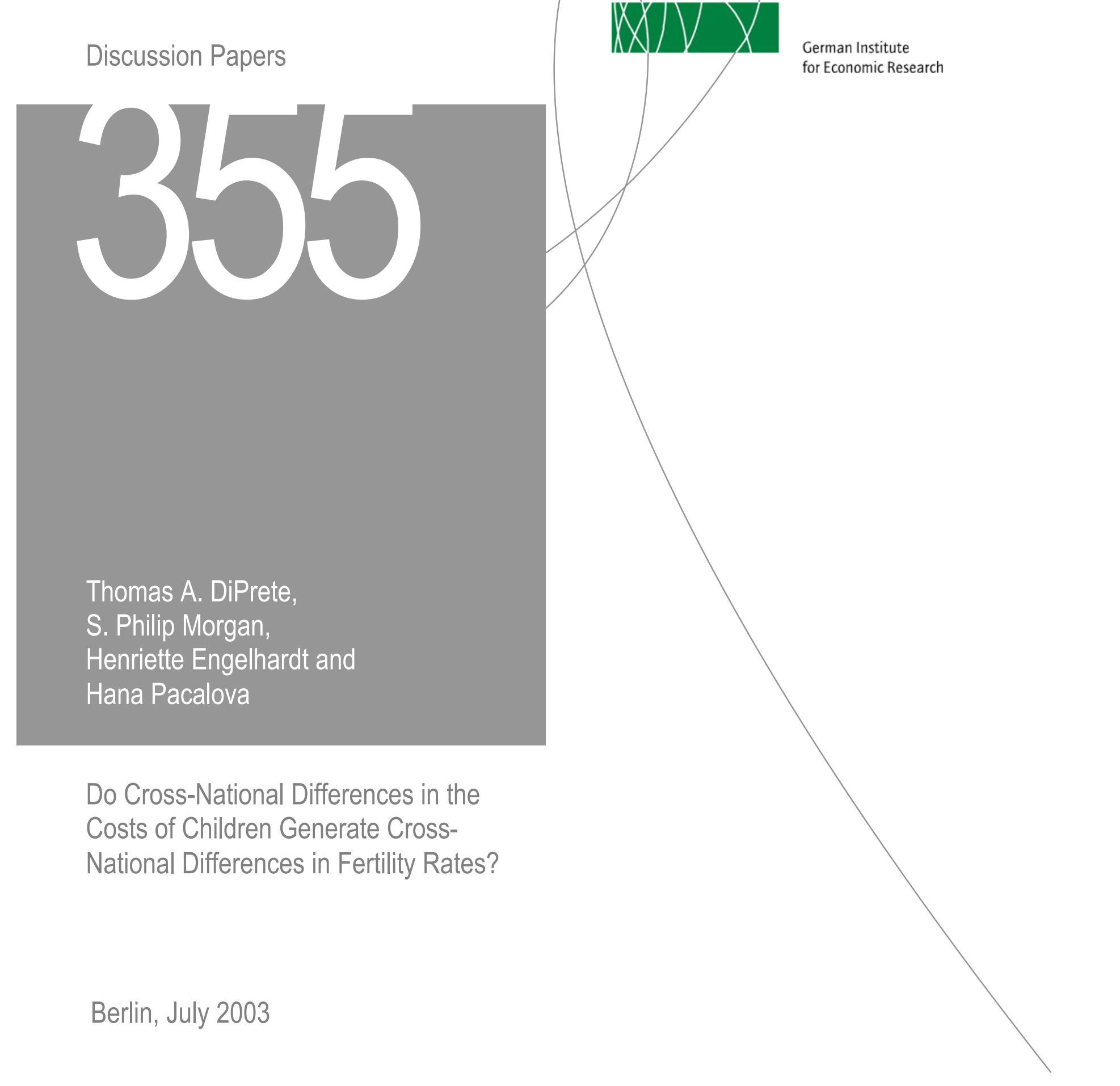


Opinions expressed in this paper are those of the author and do not necessarily reflect views of the Institute.

\section{DIW Berlin}

\section{German Institute}

for Economic Research

Königin-Luise-Str. 5

14195 Berlin,

Germany

Phone +49-30-897 89-0

Fax +49-30-897 89-200

www.diw.de

ISSN 1619-4535 
FORTHCOMING: Population Research and Policy Review (Special Issue on Low Fertility)

\title{
Do Cross-National Differences in the Costs of Children Generate Cross-National Differences in Fertility Rates?
}

\author{
Thomas A. DiPrete \\ Duke University \\ S. Philip Morgan \\ Duke University \\ Henriette Engelhardt \\ Vienna Institute for Demography, Austrian Academy of Sciences \\ Hana Pacalova \\ Duke University
}

June 16, 2003

This research has been supported by NIH grant 5 R03 HD41035-02, and by seed grants from the Vice Provost for International Affairs and the Child and Family Policy Center of Duke University. Previous versions of this paper were presented at the Seminar Series of the Child and Family Policy Center, Duke University, the Max Planck Institute for Human Development in Berlin, and the Center for Comparative Research at Yale University, and at the 2003 annual meeting of the Population Association of America. We thank the participants at these colloquiums and also Katharina Spiess and Michaela Kreyenfeld for helpful comments. We thank the German Institute of Economic Research and Eurostat for providing access to the data from the German Socioeconomic Panel and the European Community Household Panel used in this paper. Direct correspondence to Thomas A. DiPrete, Department of Sociology, Duke University, Box 90088, Durham, NC 27708-0088, email address: tdiprete@soc.duke.edu. 


\begin{abstract}
Parity-specific probabilities of having a next birth are estimated from national fertility data and are compared with nation-specific costs of having children as measured by time-budget data, by attitude data from the International Social Survey Program, and by panel data on labor earnings and standard of living changes following a birth. We focus on five countries (the US, West Germany, Denmark, Italy, and the United Kingdom), whose fertility rates span the observed fertility range in the contemporary industrialized world and whose social welfare and family policies span the conceptual space of standard welfare-state typologies. Definitive conclusions are difficult because of the multiple dimensions on which child costs can be measured, the possibility that child costs affect both the quantum and the tempo of fertility, the relatively small fertility differences across industrialized nations, and the inherent small-N problem resulting from nation-level comparisons. Empirical analysis, however, supports the assertion that institutionally driven child costs affect the fertility patterns of industrialized nations.
\end{abstract}




\section{Do Cross-National Differences in the Costs of Children Generate Cross-National Differences in Fertility Rates?}

Women's labor force participation lies at the heart of most explanations for fertility levels and change in low fertility societies. The well-documented negative association between fertility and women's labor force activity is attributed frequently to the incompatibility between caring for children and taking part in economically productive work that typifies industrialized societies (Weller 1977). Thus, women who wish to participate in the labor force must either forego or limit childbearing or make often complex and sometimes expensive arrangements for the care of their children (e.g. Kravdal 1996; Rindfuss and Brewster 1996; Brewster and Rindfuss 2000). Whatever the arrangements, the consequence of bearing a (another) child is typically lowered career earnings relative to women who forego the birth (e.g., Calhoun and Espenshade 1988; Mason and Kuhlthau 1992), though the size of these foregone earnings may vary considerably across industrialized nations (Kravdal 1992).

We expect that the difficulty of working and caring for children simultaneously will vary by social context. Key aspects of social context include (1) flexibility in work schedules, including the possibility of extended leaves of absence to have and care for children, (2) the availability, affordability, and quality of childcare, (3) the amount of help with childcare and housework that women receive from their partners, (4) economic security provided by own and partner's labor earnings, supplemented by public policies that facilitate access to and the affordability of education, health care, housing, and secure employment, and (5) the stability of marriages or cohabitations, and the economic effects of separation on the women's standard of living, as measured by size-adjusted household 
income (Folbre 1994; Rindfuss, Benjamin and Morgan 2003). These claims are entirely consistent with arguments by Esping-Anderson (1999) that low fertility can be understood only by examining the interaction of labor markets, the family, and the state.

This paper examines the relative costs of children along several dimensions in five countries: the U.S., the former West Germany, Denmark, Italy and the United Kingdom. These countries were chosen because of their recognizable differences in their labor markets, social welfare policies, and cultural orientations toward gender and the family. These countries span the four welfare state types (Anglo-American, Conservative, Social Democratic, and Mediterranean) found in theoretical discussions (Esping-Andersen 1990, 1999; Leibfried 1992) and differ in their family policies. Thus, we expect variability in the resulting level of tension between work and family for women, and arguably therefore in the costs of children (Gauthier 1996; Esping-Andersen 1999). We compare these countries in order to determine whether cross-national differences in the costs of children could account for observed differences in the pattern of fertility.

\section{Costs of ChildRen AND FeRTILITY: THEORETICAL Considerations}

The insights that child rearing involves costs and that fertility may be affected by these costs, which go back to Malthus (1933), are in the modern setting typically traced to the work of Becker and associates (Becker 1960; Becker and Lewis 1973; Becker 1993). As we show below, however, the conceptualization of these costs and how they may impact fertility has evolved greatly in the past two decades. The neoclassical approach of the "new home economists" emphasized two major costs involved with childbearing and childrearing. First there are direct monetary costs for food, clothes, 
housing, educational costs, medical costs, and so forth which rise not only with changes in the price levels of these goods and services but also with the demand for what Becker referred to as "quality" children, which, he argued, is correlated with family income. Second, the new home economists assumed a universal incompatibility between a woman's market work and her bearing and raising of children. This incompatibility implied opportunity costs, namely the earnings foregone by women as a result of reduced labor supply during pregnancy, birth, and childrearing, and the earnings foregone because future wages and job status are negatively affected by career interruption.

Given this perspective, the Becker-inspired approach, which might also be characterized as a neoclassical female wage-centered theory, treated the question as one of individual-level decisions that are driven by the market value of male and female labor (see, e.g., Willis 1973; Butz and Ward 1979; Ermisch 1988; Heckman and Walker 1990; Schultz 1994; Rönsen 1998; Di Tommaso 1999; Liefbroer and Corijn 1999; Kalwij 2000; Lundberg 2000). A higher market wage for women (e.g. from higher levels of education) is argued to have both (positive) income and (negative) substitution effects on fertility, with opposite effects on female labor force participation. The substitution effect implies that when earnings per hour increase, the opportunity cost for reducing labor hours to have more children increases, thus leading to a dampening effect on fertility. The income effect refers to the fact that when income increases (e.g. from higher education), the demand for children would increases if the quantity of children is what economists call a normal good. ${ }^{1}$ Offsetting this income effect is the postulated relationship between income and demand for what Becker referred to as "higher quality" children, who are better educated, better fed, better clothed, and who receive better medical care. Taken 
together, these arguments imply an ambiguous link between family income and the quantity of children.

Empirical evidence has not reduced this ambiguity. At the micro-level (i.e., the effort to explain individual variation in fertility in terms of individual variation in wages), some studies find support, while others do not (see e.g., Ahn and Mira 2001; Andersson 2001; DeWit and Ravanera 1998; Ermisch 1989; Hoem and Hoem 1989; Kravdal 1992; for an overview of empirical studies see Hotz et al. 1997). At the macro-level, the situation is the same. By the logic of the neoclassical model, given stable "child quality" trends toward higher wages for women would generate downward trends in fertility rates (Becker 1993; Butz and Ward 1979; Ahn and Mira 2002). But this hypothesis has received at best indirect support in the form of negative correlations between long run fertility and wage trends in industrialized societies (Mincer 1985; Becker 1993; Eckstein, Mira, and Wolpin 1998, but see e.g., Gauthier and Hatzius 1997 for contradictory results).

Similarly unsupportive results concern predictions from the neoclassical approach concerning how female labor force participation is connected to fertility. The economics approach (see the discussion in Engelhardt, Kögel, and Prskawetz 2001) tends to assume that the relationship between female labor force participation and fertility is exogenously determined by trends in wages, unemployment, and other variables - and so in this sense the association between fertility and female labor force participation can be viewed as a kind of surrogate for the underlying neoclassical prediction concerning the relationship between wages and fertility. But descriptive tabulations (Ahn and Mira 2002; Brewster and Rindfuss 2000; Rindfuss et al. 2003) show that the correlation between female labor 
force participation and fertility has actually reversed in the past fifteen years, while econometrically more rigorous analysis finds no evidence during this recent period that these variables have a causal impact on each other (Engelhardt, Kögel, and Prskawetz 2001).

Because the neoclassical female wage-centered theory poorly explains both crossnational variation in fertility levels across industrialized countries and time trends in these levels (Engelhardt and Prskawetz 2002), an alternative hypothesis has emerged. This alternative hypothesis focuses attention on the extent to which state and society have socialized the costs of raising families and thereby given women "autonomy vis-à-vis the family and the economy" (Sainsbury 1996; see also McDonald 2000a, 2000b). The neoclassical presumption that fertility and work are incompatible choices, and that this incompatibility produces a negative effect of the market wage on fertility via substitution effects, is instead theorized in the gendered approach to welfare states as a historically and geographically contingent relationship. The necessity to withdraw from the labor force when having children creates financial dependence of women on her male partner, who then functions as the family "breadwinner." States can use social policies to discourage female autonomy and promote familial dependence, e.g., through the German principle of "subsidiarity" which places the primary responsibility for social welfare on the family - more specifically the family breadwinner (Clasen and Freeman 1994; Esping-Andersen 1990). Alternatively, states can promote female autonomy from the male breadwinner by giving women the right to be "commodified" as paid labor even when they have small children, and the right to form and maintain an autonomous household even when no male breadwinner is present (Orloff 1993). Thus, the promotion 
of female familial autonomy is synonymous with the reduction of incompatibility between work and childrearing.

While the reversal in the cross-sectional correlation between female labor force participation and fertility from negative to positive suggests that the incompatibility between work and childrearing may be weakening across industrialized societies, (Brewster and Rindfuss 2000; Rindfuss, Benjamin, and Morgan 2003; Rindfuss and Brewster 1996; Pampel 2001), any universal trends in this direction are clearly proceeding at different rates in different countries (Engelhardt, Kögel, and Prskawetz 2001; Kögel 2002). ${ }^{2} \quad$ In light of the continuing large differences in social welfare policies across industrial societies, it is therefore arguable that cross-national variation in the "direct costs" of children that stem from a woman's reduced earnings are dominated not by differences in wage structures but rather by differences in the institutions that either affect the level of work-family incompatibility or that compensate families for having children at the price of reduced female contributions to household standard of living. The cost and availability of child-care, the regularity of the school calendar, the willingness of men to share domestic work, maternity leave laws and corporate policies that raise or lower the career penalty for interruptions, and that facilitate or impede flexible work schedules may play a larger role in determining the amount and duration of a labor supply reduction than would wages per se. Child costs to the household are further reduced at the individual level when these costs are socialized through subsidies for housing, education, reduced taxes or direct transfers related to the presence of children. 
All of these considerations suggest that macro-level factors may play a more important role than wages in accounting for cross-national variation in fertility rates across industrialized countries. While such a claim has intuitive appeal, macro-level explanations are difficult to confirm because the number of degrees of freedom tends to be small and the sources of macro variability large. This fundamental limitation requires an alternative set of strategies for research design and hypothesis testing.

One approach estimates the effects of specific components of a society's childcosts factors that vary at the individual level. For example, Blau and Robins (1989) analyzed the effects of a greater availability of childcare on fertility in the U.S., while Kravdal (1996) conducted a similar study for Norway, and Büchel and Spiess (2002) and Hank (2002) have conducted similar studies for western Germany. While the results of these studies have generally been in the predicted direction, the estimated effects are not strong.

A second approach has been to pool aggregate-level fertility data for a group of industrialized countries over a number of years, to introduce variables measuring the size of family benefits as well as indicators of economic conditions, and to determine whether higher family benefits tend to be associated with higher fertility across countries and over time (Ermisch 1988; Zhang et al. 1994; Caudill and Mixon 1993; Blanchet and EkertJaffé 1994; Gauthier and Hatzius 1997). Some of these studies have found that family benefits increase fertility or at least lower the age of entry into motherhood. Gauthier and Hatzius's study uses the longest time series (twenty years) and considers both the effects of cash benefits and maternity leave across 22 countries, using country and time-specific fixed effects with country-specific lagged values of fertility rates as instrumental 
variables. They find that larger monthly family allowances increase the estimated agespecific fertility rate especially for the first birth with the size of the effect being heterogeneous (larger in Scandinavia, and smaller in the Anglo-Saxon countries). At the same time, Gauthier and Hatzius found an insignificant effect on fertility rates of the duration of maternity leave or the replacement rate of pay during this leave.

The econometric results (particularly those of Gauthier and Hatzius) strongly suggest that social institutions which affect child costs influence fertility rates. At the same time, even the Gauthier and Hatzius results probably do not tell the whole story, for several reasons. First, the range of effects is small compared with the observed crossnational variation in fertility rates. ${ }^{3}$ Second, consistency of the estimator depends critically on the assumptions used to identify the model. ${ }^{4}$ Thirdly, their estimates of family benefit effects are problematic in the context of other parameter effects in their model. ${ }^{5}$ Increased affordability of children may well increase the fertility rate. If true, however, we would expect that factors which facilitate the ability of women to work while raising children could have effects that are potentially much larger than family benefits, because the amount of income to be preserved is potentially much greater. One of the problems in refining this hypothesis, however, is that the literature does not give a complete picture of the total impact of the institutional complex that affects each nation's distribution of costs related to child birth and child rearing. In our view, a determination of this distribution requires a more careful examination of the variation across countries in the multiple dimensions of child costs that together define for the potential mother the level of incompatibility between children, work, and other aspects of a modern life style. 
Our efforts are devoted to assessing these costs along three dimensions: the perceived compatibility between childrearing and work by mothers when the children are young, the time commitment that mothers must make in order to raise children, and the impact of labor supply reductions by mothers as mitigated by government tax and transfer polices on changes in the standard of living for families following a birth. These three factors are obviously interrelated. After all, it is the time commitment that a woman makes to the raising of children that constrains her ability to work. Furthermore, because two-earner families rely on the woman's wages to maintain their standard of living, earnings reductions by women will generally have a negative impact on household standard of living. Finally, one would expect a woman to perceive greater incompatibility between work and childrearing in a country where the domestic time demands on mothers are high and where the labor supply reductions following childbirth are great.

At the same time, it is also clear that the correlation between these factors can be considerably less than unity. The impact on the household standard of living from a woman's reduction in labor earnings connected with a birth will depend upon the level of partner's earnings, the pre-pregnancy ratio of mother to partner earnings, and the extent of mitigation provided to the family via family benefits. Furthermore, while one would expect women who withdraw from the labor market to do a higher share of domestic work than women who do not, differences in cultural expectations about the division of labor between male and female partners, differences in cultural expectations about the way domestic life is organized, and the availability and cultural evaluation of domestic labor-saving technology can all vary across countries (Gershuny 2000; Bianchi et al. 
2000). Finally, while one would expect women whose domestic time burdens are high to perceive a greater incompatibility between work and childrearing, the perception of incompatibility can also arise from differing cultural evaluations of the importance of full-time mothering on child development, and from cross-national differences in the valuation of individual autonomy and the sources of this autonomy, and thus the psychological and social costs and benefits of working for women as well as men. To rephrase, the impact of each of these costs in a society depends both on that country's particular mix of policies and institutional characteristics and also on the distribution of values in that society.

Fertility differences across countries result from distinctive parity-specific rate patterns. One country's fertility can be lower than another primarily because of higher proportions of childless women, or through higher proportions of women who choose to have only one child, and so forth. If one is trying to explain these differences in terms of the costs of children, it is important to consider variation in child costs with parity and across the woman's life course (e.g., Namboodiri 1972, 1983). One obvious reason for such variation would be if incremental family benefits or tax savings from the state vary according to the number of children. However, it is likely that a larger source of variation is associated with the impact of childbearing on the woman's labor force participation, and the impact of small children in the household on the number of hours that she is likely to work per week. Other sources of variation might arise from differential probabilities of union dissolution by parity. If the costs of children have an impact on the number of children, then variations in costs by parity should affect crossnational differences in parity progressions and in the timing of parity progressions. 
In the next section, we compare fertility differences between Germany, the U.S., Italy, Denmark, and the U.K. and we review institutional differences between the five countries that may contribute to differences in the average cost of children.

\section{THE FIVE-COUNTRY COMPARISON}

\section{Fertility Patterns and Trends}

From the early 1970s until the mid 1990s, the period total fertility rate was below the replacement level (of approximately 2.08) in all five countries considered in this paper. Our theoretical arguments, however, focus on parity-specific decisions made in given years. We argue that labor market effects, childcare market effects, social policy effects, and socio-cultural effects vary both cross-nationally and historically. Further, these institutional arrangements create historically and cross-nationally varying parityspecific costs of having another child. ${ }^{6}$ Thus, a theoretically appropriate measure for our analysis would be a period-specific parity progression ratio that compares births to exposure (e.g., first births to childless women.. See NiBhrolchain 1992). However given the relatively low risk of a birth (especially of a given parity) in a calendar year, the individual level panel data that we use do not provide reliable estimates of these ratios. Thus, we turn to commonly available trend data (from birth registration and census data) to calculate the total fertility rate and the parity specific total fertility rate.

These data have two weaknesses. First, the parity specific TFR is a function of a structural factor as well as a compositional one, i.e. it reflects the combination of the risk of having a child at parity $x$ (the "period parity progression ratio") and the proportion of women at parity $x$. We are exploring the sensitivity of our estimates to this compositional influence in ongoing work. Second, there is inconsistency in the reporting of parity across 
countries. Specifically, two of the five countries (Germany and the U.K.) have vital registration systems that record parity as "previous births in this union" (as opposed to number of previous births). The resulting bias is predictable; reports of births in this union increase estimates of the first and second order TFR (relative to reports of true parity). Our ongoing work also examines the magnitude of the bias introduced by this inconsistency.

While acknowledging these problems, we are confident that the general patterns described here cannot be traced to these weaknesses in the data. Thus, we take the TFR and parity-specific TFR rates for the five countries as imperfect estimates of the underlying parameters of interest. We show these estimates in Table 1 (rows 1 and 3-5). Following Bongaarts and Feeney (1998), we have also estimated the mean shift in childbearing for each parity $\left(\mathrm{r}_{\mathrm{i}}\right)$ and calculated an adjustment factor for timing shifts (1$\mathrm{r}_{\mathrm{i}}$ ); these results are shown in rows 2 and 6-8 of Panels A and B. The adjusted TFR (row 2, which is referred to as TFR') is interpreted as the period quantum of fertility or the TFR in the absence of timing shifts. In rows 6-8 of panels A and B, we calculated the parity progression ratios implied by TFR' at each parity. These parity specific TFR' estimates provide the preferred estimates of the behavioral parameters we wish to explain, i.e., in a given period and at a given parity what is the U.S. vs. W. German risk (for instance) of having another child.

\section{$\underline{\text { Table } 1 \text { about here }}$}

These data show that the five countries in this study can be broadly classified into three groups. The U.S. and the U.K., which make up the first group, have the highest overall fertility rate. Denmark's overall fertility rate is somewhat lower than that of the 
U.S. or the U.K., but this is mostly because Danish women have a considerably lower PPR from the second to the third birth. The probability that a Danish woman will have a first birth is actually as high as or higher than the corresponding probability for a British or American woman. Germany and Italy, which form the third group of countries, have the lowest fertility rates. Germany's low fertility rate is due mostly to the relatively low probability of a first birth, while Italy's low fertility rate is a consequence of its relatively low PPR at all transitions. In the next sections, we examine whether these cross-national differences in fertility are related to cross-national differences in the costs of children.

\section{Work, Time-Use and Perceived Incompatibility between Work and Childrearing}

Rates of employment by mothers with young children in the household vary considerably across the five countries in our study. At the beginning of the 1990s, the percentage of gainfully employed women with children under age six in couple-headed families was much lower in Germany, Italy, and the U.K., than in the U.S., which in turn had considerably lower rates than Denmark. Except for Denmark, which already had very high maternal employment, the rates have increased since then. The rise has been particularly fast in the U.K., which by the end of the 1990s had reached U.S. levels. Rates have risen also in Germany and Italy, but maternal employment remains considerably lower in these two countries than in the UK, the U.S., and Denmark (see Table 2). Table 2 also shows considerable differences in rates of part-time work; working mothers in the U.K. and Germany, working mothers are more likely to be parttime than in the U.S. or Italy. The cross-country pattern of employment for lone mothers is different from the pattern for coupled mothers. Italian mothers of young children, who 
are least likely to work if they have a partner, are most likely to be working full-time if they have no partner.

\section{Table 2 about here}

Cross-country differences in child-care situations fit with the big cross-national difference in employment patterns. While important cross-national differences exist in the day care coverage for older children, table 3 shows that the dramatic contrast occurs when children are under three years of age. The proportion of children under age three in formal child-care in Germany and Italy is very low. The U.K. is midway between Italy and the U.S., while Denmark has the highest coverage. ${ }^{7}$ Clearly the rates of child-care coverage across the five countries vary inversely with the rates of employment by mothers with young children.

\section{Table 3 about here}

Aggregate data reviewed so far suggest that the opportunity costs of bringing up children are higher in Germany and Italy than in the U.K., Denmark, or the U.S. due to the apparently greater difficulty of combining work and child-rearing. A key question is whether maternity benefits, family allowances and tax relief can offset the income loss due to reduced working time. As Table 3 shows, German women get 100\% of their average wage as a maternity benefit for 14 weeks (six weeks before and eight weeks after childbirth), while in Denmark paid leave lasts for 28 weeks and in Italy and the UK the benefits are 20 and 18 weeks, respectively (restrictions on these benefits, e.g., to women with sufficient prior work experience, vary by country). The United States has no statutory paid parental leave, and American women are guaranteed the right to return to 
employment following a birth for only a relatively short period of employment interruption compared to their counterparts in the four European countries.

There are also differences across countries in the average amount of time engaged in childcare and domestic labor by women with young children in the house. The greater time spent in raising and educating a child in Germany, Italy, and the U.K. provides another disincentive for a woman to combine work and family. Data from time budget surveys (OECD 2001) show that in couple-headed families with a child under five, fulltime women workers in Germany, Italy and the U.K. spend over thirty minutes per day more on domestic work than do American or Danish women. Except for the case of Italy, this extra burden seems not to be due to cross-national differences in the amount of domestic work done by male partners, but rather to differences in the organization of households that creates a larger total amount of housework to be done. ${ }^{8}$ Similar crossnational differences exist for stay-at-home mothers, with German, U.K. and Italian mothers doing over 1 hour more work per day than their counterparts in the Denmark and the U.S.

\section{Table 4 about here}

Public opinion data show strong cross-national differences in women's views concerning incompatibility between work and childrearing. In 1994, the International Social Survey Program module, "Family and Changing Gender Roles" included attitude items regarding the incompatibility of work and childrearing. Although Denmark did not participate in this survey, two other Scandinavian countries, namely Sweden and Norway, did participate, and we use them as stand-ins for Denmark. In all six countries (see table 5), women reject the idea that women should stay home and take care of the family while 
men earn money. However, the countries diverge in the proportion of women who take an affirmative stance on the value of work and who see this work as incompatible with the interests of children and families. German and Italian women are much more likely to view full-time work by women, and work in general by mothers as harmful to family life and to the development of a child (the first two items shown in Table 5). Women in Great Britain and the U.S. are much less likely to agree with these items, while women in Scandinavia are least likely to agree. Importantly, German and Italian women in particular also see work as especially important for their own life. Larger proportions of women in Italy and Germany think that work is the best way for a woman to be an "independent person." Women in Scandinavia are least likely to agree with this item, while women in the U.S. and the U.K. are again intermediate. Italian women, meanwhile, are the most likely to disagree that being a housewife is as fulfilling as working for pay, while a large majority of German and Scandinavian women also reject this assertion. British women are more likely to agree with this assertion, though agreement still comes from only a minority of women, while a bare majority of American women think that being a housewife can be as rewarding as work.

\section{Table 5 about here}

In summary, data on attitudes, on employment patterns, on family benefits, and on time spent in domestic labor suggest significant differences in the costs of children in these five countries. Denmark is the country with the highest rate of female employment, the highest availability of public childcare, and the most generous family benefits. If it is like Sweden and Norway, it is also the country with the smallest perceived incompatibility between working and child-rearing, and it has relatively low time burdens 
for mothers. Germany and Italy are the countries where work-family incompatibility seems to be the strongest; they have the highest proportion of nonworking mothers, the lowest proportion of children in formal childcare, the highest time burden of motherhood, and the highest perceived disjuncture between working, children and family life.

Germany has more generous family benefits than Italy, though it is not clear from the data presented so far whether these benefits are large enough to offset the costs of children imposed by the incompatibility between work and childrearing. The U.S. and the U.K. are intermediate on these measures. ${ }^{9}$

\section{The Consequences of Births for Earnings and Standard of Living}

We now present estimates of the impact of births on earnings and on size-adjusted household income, which we refer to as "standard of living." In order to make our estimates as comparable as possible, we present these estimates in two sets. First, we compare the U.S. and West Germany using data from the 1981-1997 waves of the Panel Study of Income Dynamics (PSID), from the 1984-2000 waves of the German Socio Economic Panel (GSOEP), and from the PSID-GSOEP Cross-National Equivalent File for these waves. These panel studies cover roughly comparable periods of time, they are long enough to allow estimates of both short and medium term consequences of a birth, and they make use of earnings and income measures from the PSID-GSOEP Equivalence file that were designed to be as comparable as possible (Burkhauser et al. 2000).

Our analyses focus on the women who were between 18 and 40 years old in the "focal year" (defined below), present in the family at the time of the interview, and reported as a head of the household or a wife/long-term cohabitor of the household head. 
We further restrict our comparison to white women in the U.S. and native Germans in the former West Germany. ${ }^{10}$

In order to broaden the comparison to the other three countries, we also analyze data from six waves of the European Community Household Panel (ECHP). Our sample for these analyses consists of female citizens between the ages of 18 and 40 in the focal year from Germany, United Kingdom, Denmark, and Italy. In the case of Germany, we restrict attention to those living in the former West Germany, excluding West Berlin. ${ }^{11}$ For the UK, we use the ECHP series that is drawn from the British Household Panel Study, while for Germany, we use the ECHP series that is drawn from the GSOEP. Therefore, the underlying data used in both the two country comparison and the four country comparison involving Germany is drawn from the same underlying source, though the specific years are different, the samples are somewhat different, and the variables in question are a subset of the GSOEP variables that were in some cases subject to additional editing by the ECHP staff. ${ }^{12}$

For the U.S. vs. West German comparison, we compute changes over time in individual labor earnings, household labor earnings, household size adjusted pretax/transfer earnings, and household size-adjusted post-tax and transfer earnings (i.e., "standard of living"). ${ }^{13}$ In the following analyses, we compare earnings and standard of living in subsequent years with earnings and standard of living two calendar years before a specific year, called the focal year, in which the event of a birth either did or did not occur. We present information not only about mean change in these values, but also about change at three important points in the earnings/standard of living distribution for each country, namely the $25^{\text {th }}, 50^{\text {th }}$ and $75^{\text {th }}$ percentile. We further restrict attention in the 
tables to women who were living in the household at the time of the interview and who were living with a partner (whether married or cohabiting) in the year before the focal year (the "lagged year"). Couples are grouped according to whether or not the birth in question was the first birth, and according to whether or not there were children younger than six living in the household in the lagged year. After controlling for these factors, we compute changes in standard of living between the calendar year two years before the focal year ("the base year") and calendar years beyond the focal year. We also compute changes in the share of labor (wage and salary and self-employment) earnings earned by the women as a function of whether there was a birth in the focal year.

The ECHP comparison is similar to the PSID-GSOEP comparison, though some differences are dictated by its study design. Aside from the shorter time-span covered by the ECHP (1994-1999), the ECHP includes household post-government tax/ transfer income but not pre-government tax/transfer income. ${ }^{14}$ Therefore, we can measure the cost of births, but not the specific extent to which these costs are mitigated by government policies. Furthermore, the ECHP does not provide information about the total number of children a woman has had. Therefore in our ECHP analyses we control for the absence of children age 0-5 at the survey date of the lagged year rather than whether the birth is a first birth. Otherwise, the ECHP data are used in parallel fashion to the PSID-GSOEP comparison; we compute the difference in the share of labor earnings by the woman in couple-headed households and the difference in standard of living according to whether or not there was a birth and according to whether or not there were already small children in the household. ${ }^{15}$ 
Our goal in these analyses is not to identify and estimate a specific regression parameter that could be defended as the "causal effect" of childbirth on standard of living (SOL) in these countries. Instead we are interested in the costs of children as a factor that potentially influences fertility decisions. We find it implausible that respondents have precise knowledge of costs that analysts struggle to uncover and estimate. Instead, we believe that respondents look around at others in their society and observe the same descriptive information that we analyze in survey data (e.g., the extent of declines in standard of living associated with a birth), and they draw their conclusions from these observations. Thus, we present the distribution of outcomes for relevant subpopulations for these five countries in order to see if the cross-national differences are distinct enough and follow an order that makes them plausible explanations for the observed crossnational differences in fertility rates.

Table 6 compares the income and standard of living response to births of American and German women who had no previous children, who had no children under the age of 18 living in the household in the previous year, and who had a partner in the household at the survey date of the previous year. The first panel shows mean estimates, while subsequent panels show responses at the $25^{\text {th }}, 50^{\text {th }}$ and $75^{\text {th }}$ percentiles of the distribution.

\section{Table 6 about here}

The first row shows that both American and German women without children provided slightly over $40 \%$ of household earnings in the base year. ${ }^{16}$ The second row shows the post-focal year share of household labor earnings, broken down by whether or not there was a birth in the focal year. The female share of labor earnings drops 
substantially following a birth in both countries, but the drop is much larger in Germany, where the mean woman went from contributing $43 \%$ to only $10 \%$ of household labor earnings. Because of this sharp drop in women's labor earnings, the German household experienced a $36 \%$ reduction in pre-tax/transfer standard of living, which is much larger than the $20 \%$ reduction for the American woman. The fourth row then shows the impact of German tax and welfare state benefits. As expected, these effects are considerably larger in Germany than in the U.S.; they mitigate the standard of living reduction by 14 percentage points, which is nearly three times the size of mitigation in the U.S. But this German advantage stemming from the social welfare system is not large enough to offset entirely the German disadvantage stemming from the reduction of female earnings. Even after taking into account of social benefits, the mean German household experiences a $22 \%$ reduction in standard of living over the three year period of time versus only a $15 \%$ reduction in the U.S. As an illustration, if we assume a size-adjusted pre-birth household income of $\$ 50,000$ (corresponding to a $\$ 70,700$ income for a two person household) in both countries, these reductions produce after birth values of $\$ 42,500$ in size-adjusted dollars three years later in the U.S. (i.e., $\$ 73,600$ in income for a three-person household) and $\$ 39,000$ in Germany (i.e., $\$ 67,500$ in income for a three-person household). This example shows that the costs of a birth are substantial and the differential cost $(\$ 3,500$ in size-adjusted dollars) is considerable. These estimates actually understate the true cost of children, because households who did not experience a birth gained in standard of living over this period of time, as shown in columns 3 and 4.

Table 7 about here 
Mean changes provide an incomplete picture of the distribution of consequences of having a child. Women have a range of earnings before a birth, have partners with a range of earnings, and reduce their labor earnings by a variable amount in response to a birth. The second, third, and fourth panels provide an indication of these variable responses, and how the distributions vary between the two countries. Standard of living declines associated with a birth are greatest at lower percentiles of the distribution in both countries. The biggest difference between the two countries can be seen at the median and the $75^{\text {th }}$ percentile. At the median, German women contribute relatively more to the household than do American women before the birth. But while American women's share of labor earnings drops by nearly half from the pre-birth median, the median German woman makes no contribution to labor earnings at all in the year following a birth. As with the previous comparisons, the German welfare state does more mitigation, but the net result is that the German household suffers a bigger fall in standard of living. The same pattern presents itself at the $75^{\text {th }}$ percentile. At the $75^{\text {th }}$ percentile, the share of post-birth labor earnings by American women is nearly as high as for mean pre-birth share of labor earnings. The German contrast to this pattern is striking; even at the $75^{\text {th }}$ percentile, the post-birth German woman contributes less than $10 \%$ of household labor earnings. While the reduction of post tax/transfer standard of living at the $75^{\text {th }}$ percentile is relatively small, it is 12 percentage points lower than the American figure.

The standard of living impact of a second child is shown in Table 7. Again the impacts of a birth are greatest on those at lower percentiles of the standard of living distribution. In contrast, the cross-national difference in the standard of living impact of a second child is relatively small. The mean impact is very similar in the two countries. 
The reason for this is readily apparent in the first two rows of Table 7 . In contrast to the first birth, German women experience a relatively small reduction in labor supply following the second birth. This puts the costs of the child in terms of labor earnings and post-government household standard of living for Germany at roughly the same level as in the U.S.

\section{Table 7 about here}

Table 8 looks an additional two years into the future and examines differences in the impact of a birth according to the average household situation over the four years following a birth according to whether the woman had previous births and had children younger than 6 in the household in the lagged year. The top panel applies to women with no previous births. These results show that the German disadvantage remains strong in terms of market income alone, but post-tax/transfer differences between nations are smaller across an average of the four years than at the two year mark. Gaps, however, persist at all four points of the distribution.

\section{Table 8 about here}

The bottom panel of Table 8 provides information about the socioeconomic impact of the second and subsequent births on standard of living change in the two countries. The results of this table can be quickly and clearly summarized. They show that German households are not at a disadvantage relative to American households concerning the costs of subsequent births. They also show the reason for this contrast. Once one child is in the household, the German family is much less reliant on the woman's labor earnings than it was before the first birth. The German tax and transfer 
system is better able to offset this smaller reduction in labor earnings in contrast to the large reduction in labor earnings following the first birth.

Next, we turn to the four-country comparison using the ECHP data. Because the ECHP panels are shorter than the PSID and GSOEP panels, we can only compute the three year change in earnings and standard of living around a birth to obtain results that are parallel to those reported in Tables 6 and 7. Table 9 contrasts Denmark, Germany, Italy and the U.K. for women who had no children under 6 in the household in the lagged year. In the base year, Italy stands out as having relatively low female earnings contributions even before the birth of a child. The birth of a child, however, has sharply different implications for female earnings in the four countries. Earnings fall relatively little in the countries at the two extremes of day care provision, namely Denmark (where formal day care is extensive) and Italy (where formal day care is meager, but where women's contribution is low even before motherhood). Employment in the U.K. drops much more sharply, while German women show by far the largest drop. By the calendar year following the birth, the German women by a considerable margin have the smallest share of labor earnings in the four countries. Italy is the second lowest by virtue of its low starting point, while the U.K. is third. When combined with possible labor supply responses by males and with state tax and transfer policies, one finds that the first birth was the most expense for the family's standard of living in Germany, followed by the U.K., Italy, and then Denmark. Simply put, the falloff in standard of living is highest in countries where the woman's contribution to household labor earnings drops the most.

Table 9 about here 
The picture is somewhat different if one contrasts women who did and did not have a birth but otherwise were similar on couple status and presence of small children (i.e., one compares the left and right columns of table 9). By this measure, Britain rises to challenge Germany as the country with the highest costs because British gains were the highest for this population over these years. This is somewhat misleading, however, for two reasons. First, a portion of the British advantage on gains comes from very young partnered women who rapidly increased their labor earnings following schooling; when we restrict the sample to women aged 22-40 (results available upon request), the outsize British gains are reduced and German relative costs are again the highest. More importantly, from a behavioral perspective, we think it dubious that women can predict societal trends in average incomes over time (even professional economists do not do this well!). If we presume that women in all four countries foresee the same benchmark SOL trajectory for the "no births" counterfactual situation, then the calculations on the left side of the table by themselves give the correct country ordering of the costs of children.

Table 10 reports the same statistics for women who had a small child in the household in the lagged year. Consistent with the results of Table 9, Danish women with small children are contributing a larger share of household labor earnings than their counterparts in Germany, Italy and the U.K., while German and Italian women have the lowest share. The consequence of a birth for this group of women is again to depress female German labor earnings the most and to depress female Italian and Danish labor earnings the least. The important difference with Table 9, however, is that German mothers with small children already contribute such a small share of labor earnings that the depressing effect of another birth is not considerable. It is at the $25^{\text {th }}$ percentile 
where the strongest country differences show up, with Italy having the highest costs. Notably, Italy's high costs at the lower parts of the distribution are not generated by the impact of the birth on the woman's earnings so much as by the combination of a small female reduction combined with apparently high male earnings instability. The next largest decline occurs in the U.K. and then Germany. The univariate statistics suggest that the declines in the UK and Germany are driven more by reductions in female earnings than is the case in Italy. At the median, the declines in the four countries are more similar, with Italy and Germany having slightly larger declines than the U.K. and Denmark. At the $75^{\text {th }}$ percentile, women in all four countries enjoy significant gains in standard of living.

\section{$\underline{\text { Table } 10 \text { about here }}$}

\section{THE IMPACT OF CHILDCARE COSTS}

Tables 6-10 have the deficiency of not taking childcare costs into account. If mothers return to work soon after giving birth but pay for some third party to care for the child while they work, this expense offsets a portion of the mother's earnings and reduces the household standard of living. Conversely, by staying home, a formerly working mother will no longer contribute to the household labor earnings, but will obviate the need for the family to pay for external childcare. The PSID contains information each year on the amount of money that families pay for childcare, but this level of detail is not available in the other household surveys. The other surveys, however, do contain some useful information that allows at least a crude estimate of the impact of differential childcare expenses on the financial impact of a birth. The GSOEP contains information 
on whether the family was paying for childcare in one specific year (1996), while the BHPS and the ECHP contained similar questions for Britain, and for Denmark and Italy.

Using this information, we computed the proportion of women in families who paid for childcare for the various subsamples shown in Tables 6-10 and report these proportions in Table 11, Panel 1. Not surprisingly, these proportions vary directly with the proportion of children in formal day care, as reported in Table 3. We have been able to find relatively little information about the average costs of daycare in various countries. Perhaps the best source is Meyers and Gornick (2000, 2003), who provide information about the proportion of each country's publicly-provided day care expenses that are paid by parents, which we reproduce in Table 11, Panel $2 .{ }^{17}$ We then estimated the actual costs for childcare in the U.S. for those who paid for childcare and the proportion of their after tax and transfer household income that they paid. As a rough approximation, we then assumed that the costs in other countries for those who paid would be in the same proportion to the U.S. costs as was the family share of childcare costs in that country relative to the U.S. ${ }^{18}$ This assumption then gives an estimate of the proportion of household income paid in the five other countries by those who paid. When multiplied by the country-specific proportion of mothers who were paying for childcare and when adjusted for household size, we obtain the adjusted costs of children shown in the bottom two rows of Table 11. This adjustment narrows slightly the standard of living gap between countries with high labor force withdrawal versus low labor force withdrawal by mothers.

$\underline{\text { Table } 11 \text { about here }}$ 


\section{DIscussion}

In Table 12 we summarize the available evidence on fertility and child costs. Generally speaking, Denmark, the U.S., and the U .K. have higher fertility rates and lower costs of children than do Germany and Italy on the nonmonetary dimensions discussed in this paper. The situation with respect to monetary costs is more complicated. At the parity zero transition, the costs for German families of a first birth appear to be definitely higher than in the other four countries, and Germany is the country whose PPR for the first birth is the lowest of the five. It is also the case that Denmark has the highest estimated PPR at parity zero, and Denmark also has the lowest estimated monetary costs to a first birth. However, Italy's lower PPR at parity zero than that of the U.S. or the U.K. does not seem attributable to the high median monetary costs of a first birth in Italy. Ambiguity also exists for the parity 1 PPR. In support of the hypothesis that costs of children influence fertility rates is our finding that the UK has the highest tempo-adjusted PPR at parity 1 and also has the lowest monetary costs from our estimates. However, the country differences estimated in our analysis at parity one appear to be small and the specific rankings of countries could very well change if the estimates could be refined or recomputed on a new sample.

Some aspects of our analyses of the monetary costs of childbirth are arguably quite robust, however. Danish women experience relatively low financial consequences

of births because of a combination of the weak effect of births on female labor supply and the heavily subsidized cost of childcare in Denmark. In Germany the monetary costs of the first birth are relatively high, because of a large labor supply reduction of women around the time of birth that is not fully made up for by welfare state benefits. In Italy, the standard of living costs of the first birth are not exceptionally high because women 
are not working in large numbers before the first birth. Finally, women in the U.S. and in the U.K. exhibit relatively high variance in their labor supply response to a birth.

Our results suggest country-specific explanations for the relative ranking of each country's fertility profile. Arguably, the U.S. has relatively high fertility because of a combination of relatively low perceived conflict between work and childbearing, relatively low domestic time demands on female housewives and workers, and the fact that the monetary costs of the first and second birth are not huge. Denmark arguably has relatively high fertility because of a combination of low nonmonetary and low monetary costs of children. Germany arguably has relatively low fertility because of a combination of high monetary costs of the first birth, relatively high time demands on women (especially housewives), and a high perceived conflict between work and childrearing. Italy arguably has low fertility because of the high nonmonetary costs of children. Finally, the relatively high U.K. fertility may be attributable to the low perceived conflict between work and childrearing, the not-high time-demands on housewives and the not-high monetary costs of having children. We note, however, that the costs analyzed in this paper do not explain why U.K. and U.S. fertility are higher than Danish fertility at parity one and at higher parities. Other factors such as additional dimensions of costs, or the extent to which women and men in these societies value children, or the timing of union formation are presumably responsible for this aspect of the country ordering of fertility rates.

As we noted earlier, the tabulations of child costs presented in this paper are essentially descriptive. They do not control in detail for individual heterogeneity. This does not mean that the results would be different if such controls were employed. With 
respect to the German-American comparison, for example, the results presented here are substantially in line with findings from DiPrete and McManus (2000), which used fixed effects regression models to control both for unmeasured permanent differences and unmeasured linear trends in standard of living, and found that increases in the number of children in the household had a more negative effect on household standard of living in Germany than in the U.S. But we continue to believe that single parameter characterizations of a country's costs are unlikely to adequately capture the perception of costs in the minds of the women and men of that country who formulate, modify and execute fertility plans over their life course.

We prefer to characterize the alignment of monetary and non-monetary costs with fertility that we described above as a set of hypotheses concerning the fertility pattern of these specific countries. As hypotheses, they need to be tested in various ways. The immediately salient question, obviously, concerns the kinds of evidence that would provide more definitive tests of their validity. One obvious test would be to find evidence of a connection between child costs and fertility across a larger number of countries. Furthermore, because the cost dimensions discussed in this paper vary within countries as well as between them, additional tests need to simultaneously exploit individual-level as well as national-level variation in seeking to verify the effects of micro and macro variation in child costs on fertility behavior.

Our work suggests that women do respond to their perception of the costs of bearing and raising children. Time out of the labor force drives up the total cost of children as does the domestic burden on women of having children. This argument suggests that policies which provide wide access and affordable childcare might have a 
positive impact on fertility, as might policies that allow for "flex-time" arrangements that allow women to work and simultaneously manage their household responsibilities. Our data also suggest that women in some countries are not persuaded that work is in the best interest of their potential children or families, and that this perception of incompatibility, coupled with their perception that work for a women is a valued source of autonomy, causes them to reduce their fertility. The resolution of this conflict arguably depends on the further development of scientific knowledge about the extent to which children are or are not harmed by their mother's working when they are very young. The resolution may also depend on a more widespread cultural acceptance of the legitimacy of a mother's working when her children are still young.

The assertion that national differences in fertility are being driven by national differences in child costs is a powerful claim that is only suggested by the evidence presented here. If confirmed in subsequent work, however, it would have major implications for public policy aimed at increasing sub-replacement fertility. 
Notes

${ }^{1}$ Whether the quantity of children is in fact a normal good (i.e., quantity rises with income) in the standard neoclassical model depends on how much of an impact the quantity of children has on their quality, and how much parents value quantity over quantity (Becker and Lewis 1973).

${ }^{2}$ Kögel (2002) showed that the time-series association between female labor force participation and total fertility has generally remained negative, and it is more negative for countries thought to have high family-work incompatibility (e.g., the Mediterranean countries) than for countries where family-work incompatibility is lower (e.g., the Scandinavian countries). It is the combination of a falling magnitude of this negative time-series association outside of the Mediterranean countries coupled with country differences in the strength of the negative time-series association across countries that generates the reversal in the sign of the cross-country correlation coefficient.

${ }^{3}$ Gauthier and Hatzius estimated that increases in family benefits of $25 \%$ (which appears to be equivalent to about a $1.3 \%$ after tax increase in a middle income husband's yearly earnings) would increase the fertility rate by about $0.6 \%$ in the short run and about $4 \%$ in the long run, which amounts to only 0.07 children per woman on average. While hardly trivial, this difference is small compared with observed variation in fertility rates across these 22 countries during 1970-1990.

${ }^{4}$ In the case of Gauthier and Hatzius, the critical assumption is that there is no second or higher order serial correlation among the residuals. But it seems unlikely that unmeasured factors (i.e., aside from average male and female wage levels, unemployment rates, and family policies) which cause one country's fertility rate to differ from another will trend according to a simple AR1 process.

${ }^{5}$ If an amount of cash equivalent to a $1.3 \%$ after tax increase in the middle-income husband's earnings triggers a rise in fertility, the effect can only be interpreted as stimulating fertility behavior that is in line with desires for children that are otherwise frustrated by income constraints. But if this were true, one would expect an increase in husband's earnings per se to increase fertility, which is contradicted by the fact that the coefficients of husband's earnings were insignificantly negative.

${ }^{6}$ Cohort trends in the distribution of completed fertility are hardly irrelevant, because these trends should reflect historically varying costs of children. It is possible that cohort enters directly into the model to the extent that behavioral responses to a specific distribution of costs at a specific historical time vary by age (since calendar time minus age equals birth cohort).

7 These statistics include formal child-care arrangements, including group-care in childcare centers (nurseries, kindergartens, and other day care centers), residential care, home based childcare provided by relatives, and care provided by a child-care worker who is not a family-member.

${ }^{8}$ Whether this could be a function of differences in male or female expectations about domestic work (e.g., concerning the preparation of meals or the level of cleanliness of the house) cannot be answered with these data. Cf. Bianchi et al. (2000) for a discussion of trends in technology and expectations in the case of the U.S. 
${ }^{9}$ Not all differences between countries cannot be completely summarized on a single dimension. For example, while work-family incompatibility in Italy appears to be high, it is still the case that a high (relative to the other countries) proportion -though still a distinct minority -- of mothers with small children manage to combine childrearing and full-time work.

10 We make these restrictions because there are important differences in the fertility behavior between whites and nonwhites in the U.S. and between native Germans in western Germany and either non-native Germans (e.g., the "Aussielders," who claim German heritage and have migrated to Germany from the former Soviet Union since the late 1980s), or native Germans in eastern Germany). African-Americans have much higher rates of out-of-wedlock fertility, and higher rates of partnership dissolution, because a higher proportion of partnerships are cohabitations. African-American women also generally work more hours than white women because of the lower earnings of black men and because of the higher frequency of female-headed households in the black community. We exclude Latinos from the American analysis because they are substantially underrepresented in the PSID. Similarly there exist important fertilityrelated differences between native West German and recent immigrant women. The latter group, aside from being ethnically rather heterogeneous, have higher average labor force participation rates, are more likely to work full time (Dustmann and Schmidt 2000), and have higher average fertility rates (Mayer and Riphan 2000). For these reasons, we limit our analysis to native West Germans and to whites in the U.S. (excluding Hispanic immigrants since 1968).

${ }^{11}$ The geographic identifiers in the ECHP do not distinguish between the former East Berlin and West Berlin.

${ }^{12}$ Another difference between the two sources is that the English-language version of the GSOEP is only a 95\% random sample of the GSOEP sample, while the ECHP data include the full $100 \%$ sample. For convenience, we will refer to the four country "ECHP data," even though the German ECHP data are drawn from the same source as the GSOEP data.

${ }^{13}$ We used the OECD equivalence scale to adjust household income for household size. We used the Equivalence-File consumer-price-index deflators to adjust German and American currencies for inflation, which are taken from the International Financial Statistics Yearbook (1999).

${ }^{14}$ Income and Earnings data for the four countries used in the ECHP analysis were deflated using data from U.S. BLS (2002).

${ }^{15}$ Our sample includes all women who met the above conditions and who were present in the household each year to give an interview. For the PSID, household information is provided by a single adult member of the household. In contrast, for the GSOEP and the ECHP surveys information is provided separately by each adult in the household. Each of these surveys provides imputation methods for information that is missing, incomplete or suspect. However, the GSOEP does not impute income or earnings figures for individuals who are adult family members but who refuse to participate in the individuallevel survey. We set household labor earnings and household income figures for these families to missing, so that they drop out of computations for years involving these missing data. With respect to the ECHP data, we followed a similar procedure with 
regards to labor earnings. The ECHP surveys (and also the BHPS and the GSOEP) also include a question asked of the adult who fills out the household survey to estimate the current net household income. We lagged this variable and multiplied it by 12 to get a yearly estimate. For years when the labor or income measures of the woman or partner were missing, we substituted this alternative measure of household income, which we then converted to a standard of living measure. All results were weighted with the recommended weights for longitudinal analysis.

${ }^{16}$ Perhaps surprisingly, this table shows that for native West Germans with no children, women at the mean contribute even a greater share of household labor earnings than do American women. This pattern arises from two reasons. First, as Blau and Kahn demonstrated (2000), the level of inequality between women and men in a society is a function of the overall level of inequality. The U.S., which has very high levels of wage inequality relative to other countries, has greater gender inequality as a direct consequence of this overall greater level of inequality. The cross-national pattern of work hours offsets this pattern somewhat. Before the first birth, German women are as likely to work as are American women (OECD 2002). However, German women without children typically work fewer hours than American women (OECD 2002). In the data under analysis here, the wage advantage for German women is larger than the disadvantage in hours worked, which explains their larger pre-birth household contribution

This result can be seen by recasting the problem in terms of the natural logarithm of the ratio of the woman's labor earnings to total earnings, which can be decomposed as the sum of the log of her wage plus the log of her annual hours minus the log of total hours. While the average log total hours for the U.S. is more positive than is the log total hours for Germany, the difference between the log of the woman and the log of total labor earnings of her and her partner is larger in Germany than in the U.S. Blau and Kahn (2000) report that the wage advantage of German women over American women was being eroded during the 1990s, so the relative size of the female share in the two countries is not necessarily stable over time.

${ }^{17}$ Aside from the U.S. (where the figures are Meyers and Gornick's estimate of the average costs across both publicly and privately provided child care), the figures from Meyers and Gornick pertain to the parents' share of the total costs for publicly-provided child care only. These figures are plausible estimates for parental share of total child care costs only to the extent that most child care in a country is provided by publicly-operated child care centers. This condition is true in Denmark (Meyers and Gornick 2003), but not in the UK. In Germany and Italy few young children receive paid care, so the distinction has no major consequences for our purposes.

${ }^{18}$ For the UK, we assumed that parents pay the same share of costs as in the U.S. 


\section{References}

Ahn, Namkee and Pedro Mira. 2001. "Job bust, baby bust: The Spanish case," Journal of Population Economics 14: 505-521.

Ahn Namkee and Pedro Mira. 2002. "A note on the changing relationship between fertility and female employment rates in developed countries," Journal of Population Economics 15: 667-682.

Andersson, Gunnar. 2001. "The impact of labour-force participation on childbearing behavior: Pro-cyclical fertility in Sweden during the 1980s and the 1990s," European Journal of Population 16: 293-333.

Bean, Frank D., Charles G. Swicegood, and Ruth Berg. 2000. "Mexican origin fertility: New patterns and interpretations," Social Science Quarterly 81: 404-420.

Becker, Gary S. 1960. "An Economic analysis of fertility," in Demographic and Economic Change in Developed Countries. Universities-National Bureau Conference Series 11. Princeton: Princeton University Press, pp. 209-231.

Becker, Gary S. 1993. A Treatise on the Family, Enlarged Edition. Cambridge, Mass.: Harvard University Press.

Becker, Gary S. and Gregg H. Lewis. 1973. "On the interaction between the quantity and quality of children," Journal of Political Economy 81: S279-S288.

Berghahn, Sabine and Andrea Fritzsche. 1991. Frauenrecht in Ost und West. Berlin: Basisdruck.

NiBhrolchain, M. (1992). "Period Paramount? A Critique of the Cohort Approach to Fertility." Population and Development Review 18: 599-629.

Bianchi, Suzanne M., Melissa A. Milkie, Liana C. Sayer, and John P. Robinson. 2000. "Is anyone doing the housework? Trends in the gender division of household labor," Social Forces 79: 191-228.

Blanchet, Didier and Olivia Ekert-Jaffé. 1994. "The Demographic impact of family benefits: Evidence from a micro-model and from macro-data," in John Ermisch and Naohiro Ogawa (eds.), The Family, the Market and the State in Ageing Societies. Oxford: Clarendon Press, pp. 79-104.

Blau, David M. and Philip K. Robins 1989. "Fertility, employment, and child-care costs," Demography 26: 287-299.

Blau, Francine D. and Lawrence M. Kahn. 2000. "Gender differences in pay," Journal of Economic Perspectives 14: 75-99.

Bongaarts, John. 1998. "Fertility and reproductive preferences in post-transitional societies," Population Council, Policy Research Division Working Paper No. 114.

Bongaarts, John and Griffith Feeney. 1998. "On the quantum and tempo of fertility," Population and Development Review 24: 271-291.

Brewster, Karin L. and Ronald R. Rindfuss. 2000. "Fertility and women's employment in industrialized nations," Annual Review of Sociology 26: 271-296. 
Büchel, Felix and Katharina Spiess. 2002. "Kindertageseinrichtungen und Mütter erwerbstätigkeit--Neue Ergebnisse zu einem bekannten Zusammenhang." Vierteljahrshefte zur Wirtschaftsforschung. 71 (1): 95-113.

Buchmann, Marlis and Maria Charles. 1995. "Organizational and Institutional Factors in the Process of Gender Stratification: Comparing Social Arrangements in Six European Countries." International Journal of Sociology 25: 66-95.

Burkhauser, Richard, Barbara A. Butrica, Mary C. Daly, and Dean R. Lillard. 2001. "The Cross-National Equivalence File: A Product of Cross-National Research." In Soziale Sicherung in einer dynamischen Gesellschaft (Social Insurance in a Dynamic Society), edited by Irene Becker, Notburga Ott, and Gabriele Rolf. Frankfurt: Campus.

Burmeister, Jürgen, Harald Christa, Bernd Halfar, and Claudia Lehnerer. 1996. "Strukturelle Unterschiede in der Ausgestaltung sozialer Sicherungssysteme in Industrieländern im Hinblick auf ihre Bedeutung für Familien," Wiesbaden: Bundesinstitut für Bevölkerungsforschung.

Butz, William P. and Michael P. Ward. 1979. "The emergence of countercyclical U.S. fertility," American Economic Review 69: 318-328.

Calhoun, Charles A. and Thomas J. Espenshade. 1988. "Childbearing and wives' foregone earnings," Population Studies 42: 5-37.

Casterline, John B., Ronald D. Lee, and Karen A. Foote. 1996. Fertility in the United States: New Patterns, New Theories. New York: Population Council.

Caudill, Steven B. and Mixon G. Franklin Jr. 1993. "A note of the effects of AFDC payments on birthrates," Rivista Internationale di Scienze Economuichie e Commerciali 40: 379-384.

Degler, Carl N. 1980. At Odds: Women and the Family in America from the Revolution to the Present. New York: Oxford University Press.

De Wit, Margaret L. and Zenaida R. Ravanera. 1998. "The changing impact of women's educational attainment on the timing of births in Canada," Canadian Studies in Population 25: 45-67.

DiPrete, Thomas A. and Patricia A. McManus. 2000. "Family change, employment transitions, and the welfare state: Household income dynamics in the United States and Germany," American Sociological Review 65: 343-370.

Di Tommaso, Maria L. 1999. "A trivariate model of participation, fertility and wages: the Italian case," Cambridge Journal of Economics 23: 623-640.

Dorbritz, Jürgen. 2001. "Familienbildungsverläufe der Generationen 1950 und 1960 im Vergleich,” Bundesinstitut für Bevölkerung, Mitteilungen 1/01: 10-14.

Dorbritz, Jürgen and Karl Schwarz. 1996. "Kinderlosigkeit in Deutschland - ein Massenphänomen?" Analysen zu Erscheingsformen und Ursachen. Zeitschrift für Bevölkerungswissenschaft 21: 231-261. 
Dustmann, Christian and Christoph M. Schmidt. 2000. "The Wage Performance of Immigrant Women: Full-Time Jobs, Part-Time Jobs, and the Role of Selection.” IZA Discussion Paper No 233. http://www.ucl.ac.uk/ uctpb21/pdf2/LS17.pdf

Eckstein, Zvi, Pedro Mira, and Kenneth I. Wolpin. 1998. "A quantitative analysis of Swedish fertility dynamics: 1751-1990," Centre for Economic Policy Research, Discussion Paper 1832.

Ejrnes, Mette, Astrid Kunze, Nina Smith and Mette Verner. 2002. "Towards a family friendly labor market policy - A comparison between Germany and Scandinavian Countries." IZA Compact, October 2002.

Engelhardt, Henriette, Tomas Kögel, and Alexia Prskawetz. 2003. "Fertility and female employment reconsidered: A macro-level time series analysis for developed countries, 1960-2000," Population Studies, forthcoming. Engelhardt, Henriette and Alexia Prskawetz. 2002. "On the changing relationship between fertility and female employment," Working Paper 2002-052, Rostock: Max Planck Institute for Demographic Research.

Ermisch, John. 1988. "Econometric analysis of birth rate dynamics in Britain," The Journal of Human Resources 23: 563-576.

Ermisch, John. 1989. "Purchased childcare, optimal family size and mother's employment: theory and econometric analysis," Journal of Population Economics 2: 79-102.

Esping-Andersen, Gøsta. 1990. The Three Worlds of Welfare Capitalism. Princeton: Princeton University Press.

Esping-Andersen, Gøsta. 1999. Social Foundations of Postindustrial Economics. Oxford: Oxford University Press.

Folbre, Nancy. 1994. Who pays for the Kids? Gender and the Structures of Constraint. New York: Routledge.

Freeman, Richard and Jochen Clasen. 1994. "The German Social State: An Introduction." Pages 1-16 in Social Policy in Germany, edited by Jochen Clasen and Richard Freeman. New York: Harvester Wheatsheaf.

Gauthier, Anne H. 1996. The State and the Family: A Comparative Analysis of Family Policies in Industrialized Countries. Oxford: Clarendon Press.

Gauthier, Anne H. and Jan Hatzius. 1997. "Family benefits and fertility: An econometric analysis," Population Studies 51: 295-306.

Gershuny, Jonathan. 2000. Changing Times: Work and Leisure in Postindustrial Society. Oxford: Oxford University Press.

Gornick, Janet C., Marcia K. Meyers, and Katherine E. Ross. 1997. "Supporting the Employment of mothers: Policy variation across fourteen welfare states," Journal of European Social Policy 7: 45-70.

Gustafsson, Siv S. and Cécile Wetzels. 2000. "Optimal age for first birth: Germany, Great Britain, the Netherlands and Sweden." in Siv S. Gustafsson and Danièle E. 
Meulders (eds.), Gender and the Labour Market: Econometric Evidence of Obstacles to Achieving Gender Equality. St. Martin's Press, New York, pp. 188-209.

Hank, Karsten. 2002. "Regional social contexts and individual fertility decisions: A multilevel analysis of first and second births in Western Germany," European Journal of Population 18: 281-299.

Heckman, James J. and James R. Walker. 1990. "The relationship between wages and income and the timing and spacing of births: Evidence from Swedish longitudinal data," Econometrica 58: 1411-1441.

Heckman, James J., Robert J. LaLonde, and Jeffrey A. Smith. 1999. “The economics and econometrics of active labor market programs," in Orley Ashenfelter and David Card (eds.), Handbook of Labor Economics, Vol. 2. Amsterdam: North Holland, pp. 18652097

Hoem, Britta and Jan M. Hoem. 1989. "The impact of women's employment on second and third births in modern Sweden," Population Studies 43: 47-67.

Hotz, Joseph V., Jacob A. Klerman, and Robert J. Willis. 1997. "The economics of fertility in developed countries," in M. R. Rosenzweig and O. Stark (eds.), Handbook of Population and Family Economics. Amsterdam: Elsevier, pp. 275-347

Kalwij, Adriaan S. 2000. "The effects of female employment status on the presence and number of children," Journal of Population Economics 13: 221-239.

Kamerman, Sheila B. 2000. "Early childhood education and care (EDEC): An overview of developments in the OECD countries," Institute for Child and Family Policy, Columbia University, www.childpolicy.org.

Kögel, Tomas. 2002. "Did the association between fertility and female employment within OECD countries really change its sign?" Working Paper 2001-034. Rostock: Max Planck Institute for Demographic Research.

Kravdal, Øystein. 1992. "Forgone labor participation and earnings due to childbearing among Norwegian women," Demography 29: 545-563.

Kravdal, Øystein. 1996. "How the local supply of day care centers influences fertility in Norway: A parity specific approach," Population Research and Policy Review 15: 201-218.

Kreyenfeld, Michaela. 2001. Employment and Fertility - East Germany in the 1990s. Unpublished Thesis, Rostock: Universität Rostock.

Leibfried, Stefan. 1992. "Towards a European Welfare State: On Integrating Poverty Regimes in the European Community." Pages 245-280 in Social Policy in a Changing Europe, edited by Z. Ferge and J.E. Kolberg. Frankfurt: Campus.

Lesthaeghe, Ron and Guy Moors. 2000. "Recent trends in fertility and household formation in the industrialized world," Review of Population and Social Policy 9: 121-170. 
Liefbroer, Aart C. and Martine Corijn. 1999. "Who, what, where and when? Specifying the impact of educational attainment and labor force participation on family formation," European Journal of Population 15: 45-75.

Lundberg, Shelly and Robert A. Pollak. 1996. "Bargaining and distribution in marriage," Journal of Economic Perspectives 10: 139-158.

Lundberg, Shelly and Eliana Rose. 2000. "Parenthood and the earnings of married men and women," Labour Economics 7: 689-710.

Malthus, Thomas R. 1933. An Essay on Population, Vol. I. London: J.M. Dent.

Mason, Karen O. and Karen Kuhltha. 1992. "The perceived impact of childcare costs on women's labor supply and fertility," Demography 29: 523-543.

Mayer, Jochen and Regina T. Riphan. 2000. "Fertility assimilation of immigrants: Evidence from count data models." Journal of Population Economics 13: 241-260.

McDonald, Peter. 2000a. "Gender Equity, Social Institutions and the Future of Fertility." Journal of Population Research 17(1):1-16.

McDonald, Peter. 2000b. "Gender Equity in Theories of Fertility Transition." Population Development Review 26(3):427-439.

Meyers, Marcia K. and Janet C. Gornick. 2000. Early Childhood Education and Care (ECEC): Cross-National Variation in Service Organization and Financing. Paper Presented for Presentation at "A Consultative Meeting on International Developments in Early Childhood Education and Care." May 11-20, 2000. New York City: Columbia University Institute for Child and Family Policy.

Meyers, Marcia K. and Janet C. Gornick. 2003. "Providing Public Care: Child Care, Preschool, Public Schooling." Unpublished manuscript.

Mincer, Jacob. 1985. "Inter-country comparisons of labor force trends and of related developments: An overview," Journal of Labor Economics 3: S1-S32.

Morgan, S. Philip and Yang Yang. 2002. "How Big Are Educational and Racial Fertility Differentials in the U.S.?" Paper presented at the annual meetings of the Population Association of America, May 9-11, Atlanta

Namboodiri, N. K. (1972). "Some observations on the economic framework for fertility analysis." Population Studies 26: 185-206.

Namboodiri, K. (1983). Sequential Fertility Decision Making and the Life Course. Determinants of Fertility in Developing Countries. R. Bulatao and R. D. Lee. New York, Academic Press 2: 444-472.

O'Donoghue, Cathal and Holly Sutherland. 1999. "Accounting for the family in European income tax systems," Cambridge Journal of Economics 23: 565-598.

OECD. 1990. Employment Outlook. Paris: Organization for Economic Cooperation and Development.

OECD. 2001. Employment Outlook. Paris: Organization for Economic Cooperation and Development. 
OECD. 2002. Employment Outlook. Paris: Organization for Economic Cooperation and Development.

Orloff, Ann Shola. 1993. "Gender and the Social Rights of Citizenship." American Sociological Review. 58: 303-328.

Pampel, Fred C. (2001). The Institutional Context of Population Change. Chicago, University of Chicago Press.

Rindfuss, Ronald R., Karen Benjamin, and S. Philip Morgan. 2000. "The changing institutional context of low fertility." Unpublished manuscript.

Rindfuss, Ronald R. and Karin L. Brewster. 1996. "Childrearing and fertility," Population and Development Review 22 (Supplement): 258-289.

Rönsen, Marit. 1998. "Fertility and public policies - Evidence from Norway and Finland," Statistics Norway, Research Department, Documents 98/12.

Roos, Patricia A. 1985. Gender and Work: A Comparative Analysis of Industrial Societies. Albany: State University of New York Press.

Sainsbury, Diane. 1996. Gender, Equality and Welfare States. Cambridge: Cambridge University Press.

Schultz, Paul T. 1994. "Marital status and fertility in the United States: Welfare and labor market effects," Journal of Human Resources 29: 637-669.

Stycos, Mayone J. and Robert H. Weller. 1967. "Female working roles and fertility," Demography 4: 210-217.

Trappe, Heike. 1995. Emanzipation oder Zwang? Frauen in der DDR zwischen Beruf, Familie und Sozialpolitik. Berlin: Akademie Verlag.

U.S. Bureau of Labor Statistics. 2002. Consumer Price Indexes, Sixteen Countries, 1950-2001. Prepared by U.S. Department of Labor, Bureau of Labor Statistics, Office of Productivity and Technology, May 20, 2002. Washington, D.C.: U.S. Government Printing Office.

Weller, Robert H. 1977. "Wife's employment and cumulative family size in the United States, 1970 and 1960," Demography. 14: 49-65.

Willis, Robert J. 1973. "A new approach to the economic theory of fertility behavior," Journal of Political Economy 81: S14-S64.

Zhang, Junxi, Jason Quan, and Peter Van Meerbergen. 1994. "The effect of tax-transfer policies on fertility in Canada, 1921-1988," Journal of Human Resources 29: 181-201. 
Table 1. Parity Progression Ratios (PPR) from Period Data, Unadjusted and Adjusted for Tempo Shifts, for Selected Countries.

\begin{tabular}{|c|c|c|c|c|c|c|c|c|}
\hline \multirow[b]{4}{*}{ Panel A: } & & & \multicolumn{6}{|c|}{ Parity-Specific Progression Ratios } \\
\hline & & & \multicolumn{3}{|c|}{ Unadjusted } & \multicolumn{3}{|c|}{ Adjusted for Tempo Shifts } \\
\hline & TFR & TFR' & $0 \rightarrow 1$ & $1 \rightarrow 2$ & $2 \rightarrow 3$ & $0 \rightarrow 1$ & $1 \rightarrow 2$ & $2 \rightarrow 3$ \\
\hline & \multicolumn{8}{|c|}{$1985-1989$} \\
\hline United States & 1.90 & 1.98 & 0.79 & 0.77 & 0.61 & 0.85 & 0.77 & 0.55 \\
\hline U.S. Non-Hispanic Whites & 1.70 & 1.88 & 0.75 & 0.79 & 0.43 & 0.86 & 0.78 & 0.47 \\
\hline Denmark & 1.52 & 1.63 & 0.70 & 0.80 & 0.50 & 0.83 & 0.81 & 0.39 \\
\hline Italy & 1.32 & 1.63 & 0.62 & 0.77 & 0.56 & 0.78 & 0.76 & 0.44 \\
\hline West Germany & 1.35 & 1.49 & 0.60 & 0.77 & 0.65 & 0.67 & 0.79 & 0.56 \\
\hline United Kingdom & 1.79 & 2.01 & 0.71 & 0.87 & 0.66 & 0.80 & 0.87 & 0.58 \\
\hline Panel B: & \multicolumn{8}{|c|}{ 1990's } \\
\hline United States (1990-94) & 2.05 & 2.17 & 0.86 & 0.75 & 0.57 & 0.89 & 0.79 & 0.56 \\
\hline U.S. Non-Hispanic Whites (1991-95) & 1.81 & 1.91 & 0.74 & 0.8 & 0.62 & 0.97 & 0.72 & 0.53 \\
\hline Denmark 1993-94 & 1.73 & 1.86 & 0.8 & 0.76 & 0.46 & 0.99 & 0.71 & 0.35 \\
\hline Italy 1993-94 & 1.22 & 1.44 & 0.62 & 0.7 & 0.48 & 0.73 & 0.70 & 0.39 \\
\hline West Germany & 1.45 & $\mathrm{n} / \mathrm{a}$ & $\mathrm{n} / \mathrm{a}$ & $\mathrm{n} / \mathrm{a}$ & $\mathrm{n} / \mathrm{a}$ & $\mathrm{n} / \mathrm{a}$ & $\mathrm{n} / \mathrm{a}$ & $\mathrm{n} / \mathrm{a}$ \\
\hline United Kingdom 1993-94 & 1.82 & 2.04 & 0.74 & 0.83 & 0.66 & 0.84 & 0.83 & 0.59 \\
\hline
\end{tabular}

Sources for above estimates:

U.S. Authors' calculations from NCHS data. Estimates are 5-year average of yearly estimates.

U.S. non-Hispanic Whites. From CPS data estimated by Morgan and Yang (2002).

Denmark, Italy and West Germany. Authors' calculations from Eurostat Data. Estimates are averages of yearly estimates. 
Table 2: Employment Patterns for Mothers with a Child under 6, Germany (including Eastern States), Italy, Denmark and the U.S.

\begin{tabular}{|c|c|c|c|c|c|}
\hline & Germany & U.S. & Italy & Denmark & U.K. \\
\hline & \multicolumn{5}{|c|}{ Couple Headed Families } \\
\hline $\begin{array}{l}\text { Proportion of mothers working } \\
-1989 / 91^{\text {a) }} \\
-1999 \\
\end{array}$ & $\begin{array}{l}49.4 \\
51.4 \\
\end{array}$ & $\begin{array}{l}55.7 \\
60.6 \\
\end{array}$ & $\begin{array}{l}40.7 \\
44.9 \\
\end{array}$ & $\begin{array}{l}85.0 \\
81.0 \\
\end{array}$ & $\begin{array}{l}45.3 \\
61.3 \\
\end{array}$ \\
\hline $\begin{array}{l}\text { Proportion with man full-time, } \\
\text { woman not working } \\
-1989 \\
-1999\end{array}$ & $\begin{array}{l}44.4 \\
41.6 \\
\end{array}$ & $\begin{array}{l}38.8 \\
35.2\end{array}$ & $\begin{array}{l}53.7 \\
47.5\end{array}$ & $\begin{array}{l}\text { n.a. } \\
\text { n.a. }\end{array}$ & $\begin{array}{l}44.5 \\
29.4 \\
\end{array}$ \\
\hline $\begin{array}{l}\text { Proportion with man full-time, } \\
\text { woman part-time } \\
\text { - } 1989 \\
-1999\end{array}$ & $\begin{array}{l}19.4 \\
26.3\end{array}$ & $\begin{array}{l}18.3 \\
18.6\end{array}$ & $\begin{array}{l}4.7 \\
9.5\end{array}$ & $\begin{array}{l}\text { n.a. } \\
\text { n.a. }\end{array}$ & $\begin{array}{l}30.7 \\
38.4 \\
\end{array}$ \\
\hline \multirow[t]{2}{*}{$\begin{array}{l}\text { Proportion with man full-time, } \\
\text { woman full-time } \\
\text { - } 1989 \\
-1999\end{array}$} & $\begin{array}{l}23.3 \\
20.9 \\
\end{array}$ & $\begin{array}{l}32.3 \\
36.5 \\
\end{array}$ & $\begin{array}{l}33.9 \\
32.6 \\
\end{array}$ & $\begin{array}{l}\text { n.a. } \\
\text { n.a. }\end{array}$ & $\begin{array}{l}13.2 \\
19.5 \\
\end{array}$ \\
\hline & \multicolumn{5}{|c|}{ Lone Parent Families } \\
\hline $\begin{array}{l}\text { Proportion with woman working } \\
\text { full-time } \\
-1989 \\
-1999\end{array}$ & $\begin{array}{l}39.1 \\
24.0 \\
\end{array}$ & $\begin{array}{l}36.0 \\
48.1 \\
\end{array}$ & $\begin{array}{l}52.8 \\
58.7 \\
\end{array}$ & $\begin{array}{l}\text { n.a. } \\
\text { n.a. }\end{array}$ & $\begin{array}{c}7.2 \\
12.5 \\
\end{array}$ \\
\hline $\begin{array}{l}\text { Proportion with woman not } \\
\text { working } \\
-1989 \\
-1999\end{array}$ & $\begin{array}{l}40.6 \\
52.1 \\
\end{array}$ & $\begin{array}{l}54.6 \\
34.4 \\
\end{array}$ & $\begin{array}{l}40.8 \\
30.5 \\
\end{array}$ & $\begin{array}{l}\text { n.a. } \\
\text { n.a. }\end{array}$ & $\begin{array}{l}76.4 \\
65.8 \\
\end{array}$ \\
\hline
\end{tabular}

Notes: a) Data for Germany refer to 1991, Data for the U.S. and the U.K. to 1989, Data for Denmark to 1990 and 1997.

Source: OECD Employment Outlook (2001: 134f), Ejrnes et al. (2002). 
Table 3: Formal Child-Care Coverage, Statutory Parental Leave Policies, and Tax and Family Allowance Policies.

\begin{tabular}{|c|c|c|c|c|c|}
\hline & Germany & U.S. & Denmark & Italy & U.K. \\
\hline $\begin{array}{l}\text { Proportion of children under } \\
3 \text { in formal childcare }\end{array}$ & 10 & 54 & 64 & 6 & 34 \\
\hline $\begin{array}{l}\text { Proportion of children from } \\
3 \text { to mandatory school age } \\
\text { in formal childcare }\end{array}$ & 78 & 70 & 91 & 95 & 60 \\
\hline Legislated job protection & yes & no & yes & yes & yes \\
\hline Paid maternity leave (weeks) & 14 & 0 & 30 & 21.5 & 18 \\
\hline $\begin{array}{l}\text { Wage replacement rate }(\% \\
\text { wages })\end{array}$ & 100 & 0 & 100 & 80 & 46 \\
\hline $\begin{array}{l}\text { Coverage (\% of employed } \\
\text { women) }\end{array}$ & 100 & 25 & 100 & 100 & 60 \\
\hline $\begin{array}{l}\text { Consecutive weeks of } \\
\text { maternity and parental leave }\end{array}$ & 162 & 12 & 60.5 & 64.5 & 44 \\
\hline $\begin{array}{l}\text { Weeks of paid maternity } \\
\text { leave }\end{array}$ & 14 & 0 & 28 & 20 & 18 \\
\hline Paternity benefits & yes & no & Yes & yes & no \\
\hline Taxation of couples & $\begin{array}{r}\text { Optional } \\
\text { joint } \\
\text { (income } \\
\text { splitting) }\end{array}$ & Individual & Individual & $\begin{array}{r}\text { Individual, } \\
\text { Capital } \\
\text { income } \\
\text { taxed } \\
\text { jointly }\end{array}$ & $\begin{array}{r}\text { Individual } \\
\text { since } \\
1991\end{array}$ \\
\hline $\begin{array}{l}\text { Family allowances } \\
\text { (as percent of avg. male } \\
\text { manufacturing wage) }\end{array}$ & $4.9 \%$ & $--^{a}$ & $5.2 \%$ & $0 \%$ & $6.3 \%$ \\
\hline $\begin{array}{l}\text { Tax relief and family } \\
\text { allowance as percent of the } \\
\text { avg. male manufacturing } \\
\text { wage (comparing single- } \\
\text { earner couple with } 2 \text { children } \\
\text { with single person) }\end{array}$ & $21.2 \%$ & $9.7 \%$ & $26.3 \%$ & $14.5 \%$ & $12.7 \%$ \\
\hline
\end{tabular}

Notes: Statistics for the child-care coverage refers to 1995 for the United States, 1998 for Denmark and Italy, and 2000 for the U.K. and Denmark. Statistics for paid maternity leave refer to 1990, family allowances and tax effects are for 1990 .

Note (a) Only Means tested benefits are available.

Source: OECD (2001: 144); Gornick et al. (1997: 57); Gauthier (1996; p. 166, 174) 
Table 4: Average Time Spent on Child-Care and Domestic Labor per Day in Couple Families with a Child under 5 in united Germany, U.S., Italy, Denmark and the U.K.

\begin{tabular}{|c|c|c|c|c|c|}
\hline & $\begin{array}{c}\text { Germany } \\
1992 \\
\end{array}$ & $\begin{array}{r}\text { U.S. } \\
1995 \\
\end{array}$ & $\begin{array}{l}\text { Italy } \\
1989 \\
\end{array}$ & $\begin{array}{c}\text { Denmark } \\
1987 \\
\end{array}$ & $\begin{array}{l}\text { U.K. } \\
1995 \\
\end{array}$ \\
\hline & \multicolumn{5}{|c|}{ Childcare (Minutes) } \\
\hline Men & 59 & 33 & 36 & 28 & 87 \\
\hline Women in full time jobs & 124 & 62 & 96 & 55 & 120 \\
\hline Women in part time jobs & 142 & 93 & n.a. & 41 & 154 \\
\hline \multirow[t]{2}{*}{ Housewives } & 175 & 106 & 120 & 87 & 205 \\
\hline & \multicolumn{5}{|c|}{ Other Unpaid Work (Hours) } \\
\hline Men & 2.5 & 2.0 & 1.2 & 1.9 & 1.7 \\
\hline Women in full time jobs & 4.2 & 3.3 & 4.8 & 3.1 & 5.4 \\
\hline Women in part time jobs & 5.0 & 3.1 & n.a. & 4.1 & 4.2 \\
\hline \multirow[t]{2}{*}{ Housewives } & 5.8 & 4.4 & 7.0 & 5.4 & 4.7 \\
\hline & \multicolumn{5}{|c|}{ Total Domestic Work (Hours) } \\
\hline Men & 3.5 & 2.6 & 1.8 & 2.4 & 3.2 \\
\hline Women in full time jobs & 6.3 & 4.3 & 6.4 & 4.0 & 7.4 \\
\hline Women in part time jobs & 7.4 & 4.7 & n.a. & 4.8 & 6.8 \\
\hline Housewives & 8.7 & 6.2 & 9.0 & 6.9 & 8.1 \\
\hline
\end{tabular}

Source: OECD (2001: 140). 
Table 5: Percentage of Women Aged 18 to 35 who Agree or Strongly Agree

\begin{tabular}{|c|c|c|c|c|c|c|}
\hline & Germany & Great Britain & United States & Italy & Norway & Sweden \\
\hline $\begin{array}{l}\text { A pre-school child is likely to } \\
\text { suffer if his/her mother works. }\end{array}$ & $61.2 \%$ & $\begin{array}{c}23.9 \% \\
(24.9 \%)\end{array}$ & $25.5 \%$ & $\begin{array}{l}60.9 \% \\
(61.0 \%)\end{array}$ & $18.4 \%$ & $\begin{array}{c}18.0 \% \\
(18.0 \%)\end{array}$ \\
\hline $\begin{array}{l}\text { All in all, family life suffers when } \\
\text { a woman has a full-time job. }\end{array}$ & $48.5 \%$ & $\begin{array}{l}23.2 \% \\
(21.5 \%)\end{array}$ & $21.5 \%$ & $\begin{array}{c}46.9 \% \\
(48.7 \%)\end{array}$ & $24.8 \%$ & $\begin{array}{l}23.2 \% \\
(24.6 \%)\end{array}$ \\
\hline $\begin{array}{l}\text { Being a housewife is just as } \\
\text { fulfilling as working for pay. }\end{array}$ & $30.4 \%$ & $\begin{array}{l}42.9 \% \\
(41.9 \%)\end{array}$ & $53.3 \%$ & $\begin{array}{l}16.8 \% \\
(17.5 \%)\end{array}$ & $25.2 \%$ & $\begin{array}{l}24.4 \% \\
(24.0 \%)\end{array}$ \\
\hline $\begin{array}{l}\text { Having a job is the best way for a } \\
\text { woman to be an independent } \\
\text { person. }\end{array}$ & $79.8 \%$ & $\begin{array}{l}55.1 \% \\
(54.0 \%)\end{array}$ & $50.5 \%$ & $\begin{array}{l}80.1 \% \\
(79.8 \%)\end{array}$ & $39.3 \%$ & $\begin{array}{c}47.8 \% \\
(46.2 \%)\end{array}$ \\
\hline $\begin{array}{l}\text { A man's job is to earn money; a } \\
\text { woman's job is to look after the } \\
\text { home and family. }\end{array}$ & $17.7 \%$ & $\begin{array}{l}10.7 \% \\
(11.3 \%)\end{array}$ & $8.4 \%$ & $\begin{array}{l}11.7 \% \\
(13.1 \%)\end{array}$ & $4.0 \%$ & $\begin{array}{c}9.1 \% \\
(9.9 \%)\end{array}$ \\
\hline
\end{tabular}

Source: ISSP 1994, own calculations, unweighted results. Weights were not available for all countries. Where available, weighted results are shown in parentheses. Data for Germany are for the former West-Germany only. 
Table 6

Income and Standard of Living Changes in Response to Birth, for Women 18-40 in Focal Year Comparing One Calendar Year Ahead of the Focal Year with Two Years before the Focal Year

No Previous Children, Partner in HH at Survey Date of Previous Year

\begin{tabular}{|c|c|c|c|c|c|c|c|c|}
\hline \multirow[b]{3}{*}{ Mean Effects } & \multicolumn{4}{|c|}{ Birth in Focal Year } & \multicolumn{4}{|c|}{ No Birth in Focal Year } \\
\hline & \multicolumn{2}{|c|}{$\begin{array}{c}\text { Ethnic Germans in } \mathrm{W} . \\
\text { Germany }\end{array}$} & \multicolumn{2}{|c|}{ U.S. Whites } & \multicolumn{2}{|c|}{$\begin{array}{c}\text { Ethnic Germans in } \mathrm{W} . \\
\text { Germany }\end{array}$} & \multicolumn{2}{|c|}{ U.S. Whites } \\
\hline & Estimate & S.E. & Estimate & S.E. & Estimate & S.E. & Estimate & S.E. \\
\hline Share of Base Year HH Labor Earnings & $43 \%$ & $2 \%$ & $39 \%$ & $1 \%$ & $43 \%$ & $1 \%$ & $39 \%$ & $1 \%$ \\
\hline Share of Post-Focal Year HH Labor Earnings & $10 \%$ & $2 \%$ & $28 \%$ & $2 \%$ & $45 \%$ & $2 \%$ & $44 \%$ & $1 \%$ \\
\hline Change in Pre-Tax/Transfer Size Adjusted HH Income & $-36 \%$ & $2 \%$ & $-20 \%$ & $3 \%$ & $14 \%$ & $3 \%$ & $7 \%$ & $2 \%$ \\
\hline Change in Post Tax/Transfer Size Adjusted HH Income & $-22 \%$ & $2 \%$ & $-15 \%$ & $2 \%$ & $11 \%$ & $2 \%$ & $7 \%$ & $2 \%$ \\
\hline \multicolumn{9}{|l|}{ 25th Percentile } \\
\hline Share of Base Year HH Labor Earnings & $32 \%$ & & $27 \%$ & & $25 \%$ & & $27 \%$ & \\
\hline Share of Post-Focal Year HH Labor Earnings & $0 \%$ & & $1 \%$ & & $29 \%$ & & $28 \%$ & \\
\hline Change in Pre-Tax/Transfer Size Adjusted HH Income & $-50 \%$ & & $-35 \%$ & & $-5 \%$ & & $-9 \%$ & \\
\hline Change in Post Tax/Transfer Size Adjusted HH Income & $-36 \%$ & & $-28 \%$ & & $-4 \%$ & & $-7 \%$ & \\
\hline \multicolumn{9}{|l|}{ Median } \\
\hline Share of Base Year HH Labor Earnings & $43 \%$ & & $39 \%$ & & $43 \%$ & & $40 \%$ & \\
\hline Share of Post-Focal Year HH Labor Earnings & $0 \%$ & & $22 \%$ & & $43 \%$ & & $42 \%$ & \\
\hline Change in Pre-Tax/Transfer Size Adjusted HH Income & $-38 \%$ & & $-18 \%$ & & $19 \%$ & & $15 \%$ & \\
\hline Change in Post Tax/Transfer Size Adjusted HH Income & $-23 \%$ & & $-15 \%$ & & $15 \%$ & & $16 \%$ & \\
\hline \multicolumn{9}{|l|}{ 75th Percentile } \\
\hline Share of Base Year HH Labor Earnings & $51 \%$ & & $48 \%$ & & $54 \%$ & & $50 \%$ & \\
\hline Share of Post-Focal Year HH Labor Earnings & $8 \%$ & & $43 \%$ & & $56 \%$ & & $57 \%$ & \\
\hline Change in Pre-Tax/Transfer Size Adjusted HH Income & $-18 \%$ & & $6 \%$ & & $65 \%$ & & $50 \%$ & \\
\hline Change in Post Tax/Transfer Size Adjusted HH Income & $-5 \%$ & & $7 \%$ & & $43 \%$ & & $47 \%$ & \\
\hline $\mathbf{N}$ (distinct individuals) & 319 & & 342 & & 627 & & 484 & \\
\hline
\end{tabular}


Table 7

Income and Standard of Living Changes in Response to Birth, for Women 18-40 in Focal Year Comparing One Calendar Year Ahead of the Focal Year with Two Years before the Focal Year

Children Under 6 in HH, Partner in HH at Survey Date of Previous Year

\begin{tabular}{|c|c|c|c|c|c|c|c|c|}
\hline \multirow[b]{3}{*}{ Mean Effects } & \multicolumn{4}{|c|}{ Birth in Focal Year } & \multicolumn{4}{|c|}{ No Birth in Focal Year } \\
\hline & \multicolumn{2}{|c|}{$\begin{array}{c}\text { Ethnic Germans in W. } \\
\text { Germany }\end{array}$} & \multicolumn{2}{|c|}{ U.S. Whites } & \multicolumn{2}{|c|}{$\begin{array}{c}\text { Ethnic Germans in W. } \\
\text { Germany }\end{array}$} & \multicolumn{2}{|c|}{ U.S. Whites } \\
\hline & Estimate & S.E. & Estimate & S.E. & Estimate & S.E. & Estimate & S.E. \\
\hline Share of Base Year HH Labor Earnings & $16 \%$ & $2 \%$ & $22 \%$ & $1 \%$ & $13 \%$ & $1 \%$ & $21 \%$ & $1 \%$ \\
\hline Share of Post-Focal Year HH Labor Earnings & $7 \%$ & $2 \%$ & $23 \%$ & $1 \%$ & $17 \%$ & $1 \%$ & $29 \%$ & $1 \%$ \\
\hline Change in Pre-Tax/Transfer Size Adjusted HH Income & $-17 \%$ & $3 \%$ & $-17 \%$ & $2 \%$ & $2 \%$ & $2 \%$ & $-1 \%$ & $1 \%$ \\
\hline Change in Post Tax/Transfer Size Adjusted HH Income & $-11 \%$ & $2 \%$ & $-12 \%$ & $2 \%$ & $0 \%$ & $1 \%$ & $3 \%$ & $1 \%$ \\
\hline 25th Percentile & & & & & & & & \\
\hline Share of Base Year HH Labor Earnings & $0 \%$ & & $1 \%$ & & $0 \%$ & & $0 \%$ & \\
\hline Share of Post-Focal Year HH Labor Earnings & $0 \%$ & & $0 \%$ & & $0 \%$ & & $0 \%$ & \\
\hline Change in Pre-Tax/Transfer Size Adjusted HH Income & $-35 \%$ & & $-36 \%$ & & $-27 \%$ & & $-30 \%$ & \\
\hline Change in Post Tax/Transfer Size Adjusted HH Income & $-27 \%$ & & $-29 \%$ & & $-23 \%$ & & $-23 \%$ & \\
\hline Median & & & & & & & & \\
\hline Share of Base Year HH Labor Earnings & $9 \%$ & & $21 \%$ & & $7 \%$ & & $17 \%$ & \\
\hline Share of Post-Focal Year HH Labor Earnings & $0 \%$ & & $12 \%$ & & $2 \%$ & & $22 \%$ & \\
\hline Change in Pre-Tax/Transfer Size Adjusted HH Income & $-17 \%$ & & $-13 \%$ & & $-4 \%$ & & $-7 \%$ & \\
\hline Change in Post Tax/Transfer Size Adjusted HH Income & $-10 \%$ & & $-10 \%$ & & $-3 \%$ & & $-2 \%$ & \\
\hline 75th Percentile & & & & & & & & \\
\hline Share of Base Year HH Labor Earnings & $32 \%$ & & $38 \%$ & & $33 \%$ & & $39 \%$ & \\
\hline Share of Post-Focal Year HH Labor Earnings & $3 \%$ & & $39 \%$ & & $26 \%$ & & $46 \%$ & \\
\hline Change in Pre-Tax/Transfer Size Adjusted HH Income & $2 \%$ & & $12 \%$ & & $20 \%$ & & $22 \%$ & \\
\hline Change in Post Tax/Transfer Size Adjusted HH Income & $7 \%$ & & $12 \%$ & & $13 \%$ & & $21 \%$ & \\
\hline $\mathrm{N}$ (distinct individuals) & 336 & & 483 & & 864 & & 1016 & \\
\hline
\end{tabular}




\section{Table 8}

Income and Standard of Living Changes in Response to Birth, for Women 18-40 in Focal Year Comparing Average 4 years from Birth Year with Two Years before the Focal Year

\begin{tabular}{|c|c|c|c|c|c|c|c|c|}
\hline \multirow{4}{*}{$\begin{array}{l}\text { Estimated Change in Standard of } \\
\text { Living }\end{array}$} & \multicolumn{4}{|c|}{ Birth in Focal Year } & \multicolumn{4}{|c|}{ No Birth in Focal Year } \\
\hline & \multicolumn{2}{|c|}{$\begin{array}{l}\text { Ethnic Germans in } \\
\text { W. Germany }\end{array}$} & \multicolumn{2}{|c|}{ U.S. Whites } & \multicolumn{2}{|c|}{$\begin{array}{l}\text { Ethnic Germans in } \\
\text { W. Germany }\end{array}$} & \multicolumn{2}{|c|}{ U.S. Whites } \\
\hline & Estimate & S.E. & Estimate & S.E. & Estimate & S.E. & Estimate & S.E. \\
\hline & \multicolumn{8}{|c|}{ No Previous Children } \\
\hline Mean: Pre-Tax/Transfer SOL ${ }^{a}$ & $-26 \%$ & $2 \%$ & $-14 \%$ & $2 \%$ & $12 \%$ & $3 \%$ & $11 \%$ & $2 \%$ \\
\hline Mean: Post-Tax/Transfer SOL & $-14 \%$ & $2 \%$ & $-10 \%$ & $2 \%$ & $12 \%$ & $2 \%$ & $10 \%$ & $2 \%$ \\
\hline 25th Pct: Pre-Tax/Transfer SOL & $-40 \%$ & & $-32 \%$ & & $-8 \%$ & & $-11 \%$ & \\
\hline 25th Pct: Pre-Tax/Transfer SOL & $-28 \%$ & & $-26 \%$ & & $-3 \%$ & & $-8 \%$ & \\
\hline Median: Pre-Tax/Transfer SOL & $-29 \%$ & & $-14 \%$ & & $14 \%$ & & $16 \%$ & \\
\hline Median: Pre-Tax/Transfer SOL & $-15 \%$ & & $-11 \%$ & & $15 \%$ & & $14 \%$ & \\
\hline 75th Pct: Pre-Tax/Transfer SOL & $-10 \%$ & & $8 \%$ & & $53 \%$ & & $49 \%$ & \\
\hline 75th Pct: Pre-Tax/Transfer SOL & $-1 \%$ & & $9 \%$ & & $42 \%$ & & $43 \%$ & \\
\hline \multirow[t]{2}{*}{$\mathbf{N}$ (distinct individuals) } & 273 & & 300 & & 514 & & 411 & \\
\hline & \multicolumn{8}{|c|}{ Children Under 6 in Household } \\
\hline Mean: Pre-Tax/Transfer SOL & $-10 \%$ & $3 \%$ & $-8 \%$ & $2 \%$ & $4 \%$ & $2 \%$ & $4 \%$ & $1 \%$ \\
\hline Mean: Post-Tax/Transfer SOL & $-6 \%$ & $2 \%$ & $-4 \%$ & $2 \%$ & $2 \%$ & $1 \%$ & $6 \%$ & $1 \%$ \\
\hline 25th Pct: Pre-Tax/Transfer SOL & $-33 \%$ & & $-26 \%$ & & $-25 \%$ & & $-24 \%$ & \\
\hline 25th Pct: Pre-Tax/Transfer SOL & $-25 \%$ & & $-22 \%$ & & $-20 \%$ & & $-19 \%$ & \\
\hline Median: Pre-Tax/Transfer SOL & $-11 \%$ & & $-7 \%$ & & $-3 \%$ & & $-4 \%$ & \\
\hline Median: Pre-Tax/Transfer SOL & $-4 \%$ & & $-4 \%$ & & $-3 \%$ & & $0 \%$ & \\
\hline 75th Pct: Pre-Tax/Transfer SOL & $8 \%$ & & $16 \%$ & & $21 \%$ & & $20 \%$ & \\
\hline 75th Pct: Pre-Tax/Transfer SOL & $10 \%$ & & $15 \%$ & & $14 \%$ & & $21 \%$ & \\
\hline N (distinct individuals) & 276 & & 403 & & 723 & & 894 & \\
\hline
\end{tabular}

Notes a SOL ("standard of living") is the size-adjusted household income 
Table 9

Income and Standard of Living Changes in Response to Birth, for Women 18-40 in Focal Year Comparing One Calendar Year Ahead of the Focal Year with Two Years before the Focal Year

No Children 0-5 and Partner in HH at Survey Date of Previous Year, 1994-1999

\begin{tabular}{|c|c|c|c|c|c|c|c|c|}
\hline \multirow[b]{3}{*}{ Mean Effects } & \multicolumn{4}{|c|}{ Birth in Focal Year } & \multicolumn{4}{|c|}{ No Birth in Focal Year } \\
\hline & Denmark & West Germany & Italy & UK & Denmark & $\begin{array}{c}\text { West } \\
\text { Germany }\end{array}$ & Italy & UK \\
\hline & Estimate S.E. & Estimate S.E. & Estimate S.E. & Estimate S.E. & Estimate S.E. & Estimate S.E. & Estimate S.E. & Estimate S.E. \\
\hline Share of Base Year HH Labor Earnings & $42 \% \quad 2 \%$ & $36 \% \quad 7 \%$ & $26 \% 2 \%$ & $47 \% 2 \%$ & $38 \% \quad 2 \%$ & $28 \% \quad 1 \%$ & $25 \% \quad 1 \%$ & $38 \% \quad 1 \%$ \\
\hline Share of Focal Year HH Labor Earnings & $37 \% \quad 3 \%$ & $28 \% \quad 3 \%$ & $26 \% \quad 2 \%$ & $39 \% \quad 3 \%$ & $42 \% \quad 1 \%$ & $34 \% \quad 2 \%$ & $25 \% \quad 1 \%$ & $39 \% \quad 1 \%$ \\
\hline Share of 1st Post-Focal Year HH Labor Earnings & $39 \% \quad 3 \%$ & $5 \% \quad 2 \%$ & $25 \% \quad 2 \%$ & $31 \% \quad 3 \%$ & $42 \% \quad 1 \%$ & $35 \% \quad 2 \%$ & $26 \% \quad 1 \%$ & $40 \% \quad 1 \%$ \\
\hline Change in Woman's Labor Income & $-15 \% \quad 10 \%$ & $-76 \% \quad 6 \%$ & $-7 \% \quad 7 \%$ & $-46 \% 5 \%$ & $21 \% 7 \%$ & $14 \% \quad 4 \%$ & $7 \% \quad 3 \%$ & $18 \% 4 \%$ \\
\hline Change in Post Tax/Transfer Size Adjusted HH Income & $-11 \% \quad 3 \%$ & $-21 \% \quad 5 \%$ & $-10 \% 5 \%$ & $-14 \% 4 \%$ & $7 \% \quad 2 \%$ & $0 \% 2 \%$ & $3 \% 2 \%$ & $11 \% 2 \%$ \\
\hline 25th Percentile & & & & & & & & \\
\hline Share of Base Year HH Labor Earnings & $34 \%$ & $13 \%$ & $0 \%$ & $36 \%$ & $24 \%$ & $3 \%$ & $0 \%$ & $17 \%$ \\
\hline Share of Focal Year HH Labor Earnings & $26 \%$ & $9 \%$ & $0 \%$ & $20 \%$ & $31 \%$ & $9 \%$ & $0 \%$ & $20 \%$ \\
\hline Share of 1st Post-Focal Year HH Labor Earnings & $24 \%$ & $0 \%$ & $0 \%$ & $0 \%$ & $31 \%$ & $9 \%$ & $0 \%$ & $22 \%$ \\
\hline Change in Woman's Labor Income & $-40 \%$ & $-86 \%$ & $-15 \%$ & $-85 \%$ & $-12 \%$ & $-9 \%$ & $-4 \%$ & $-7 \%$ \\
\hline Change in Post Tax/Transfer Size Adjusted HH Income & $-24 \%$ & $-36 \%$ & $-35 \%$ & $-33 \%$ & $-15 \%$ & $-14 \%$ & $-21 \%$ & $-11 \%$ \\
\hline Median & & & & & & & & \\
\hline Share of Base Year HH Labor Earnings & $43 \%$ & $39 \%$ & $25 \%$ & $46 \%$ & $39 \%$ & $25 \%$ & $20 \%$ & $38 \%$ \\
\hline Share of Focal Year HH Labor Earnings & $39 \%$ & $27 \%$ & $21 \%$ & $36 \%$ & $42 \%$ & $32 \%$ & $17 \%$ & $38 \%$ \\
\hline Share of 1st Post-Focal Year HH Labor Earnings & $39 \%$ & $0 \%$ & $23 \%$ & $28 \%$ & $42 \%$ & $29 \%$ & $20 \%$ & $38 \%$ \\
\hline Change in Woman's Labor Income & $-1 \%$ & $-86 \%$ & $0 \%$ & $-24 \%$ & $9 \%$ & $0 \%$ & $0 \%$ & $11 \%$ \\
\hline Change in Post Tax/Transfer Size Adjusted HH Income & $-10 \%$ & $-22 \%$ & $-12 \%$ & $-15 \%$ & $3 \%$ & $-2 \%$ & $0 \%$ & $11 \%$ \\
\hline 75th Percentile & & & & & & & & \\
\hline Share of Base Year HH Labor Earnings & $49 \%$ & $48 \%$ & $48 \%$ & $56 \%$ & $49 \%$ & $42 \%$ & $45 \%$ & $52 \%$ \\
\hline Share of Focal Year HH Labor Earnings & $49 \%$ & $33 \%$ & $45 \%$ & $51 \%$ & $50 \%$ & $49 \%$ & $45 \%$ & $51 \%$ \\
\hline Share of 1st Post-Focal Year HH Labor Earnings & $47 \%$ & $3 \%$ & $45 \%$ & $51 \%$ & $51 \%$ & $50 \%$ & $45 \%$ & $55 \%$ \\
\hline Change in Woman's Labor Income & $28 \%$ & $-23 \%$ & $0 \%$ & $8 \%$ & $98 \%$ & $39 \%$ & $11 \%$ & $67 \%$ \\
\hline Change in Post Tax/Transfer Size Adjusted HH Income & $4 \%$ & $-18 \%$ & $11 \%$ & $7 \%$ & $33 \%$ & $18 \%$ & $28 \%$ & $48 \%$ \\
\hline $\mathbf{N}$ (distinct individuals) & 77 & 107 & 228 & 160 & 340 & 685 & 1012 & 805 \\
\hline
\end{tabular}




\section{Table 10}

Income and Standard of Living Changes in Response to Birth, for Women 18-40 in Focal Year Comparing One Calendar Year Ahead of the Focal Year with Two Years before the Focal Year

\section{Some Children 0-5 and Partner in HH at Survey Date of Previous Year}

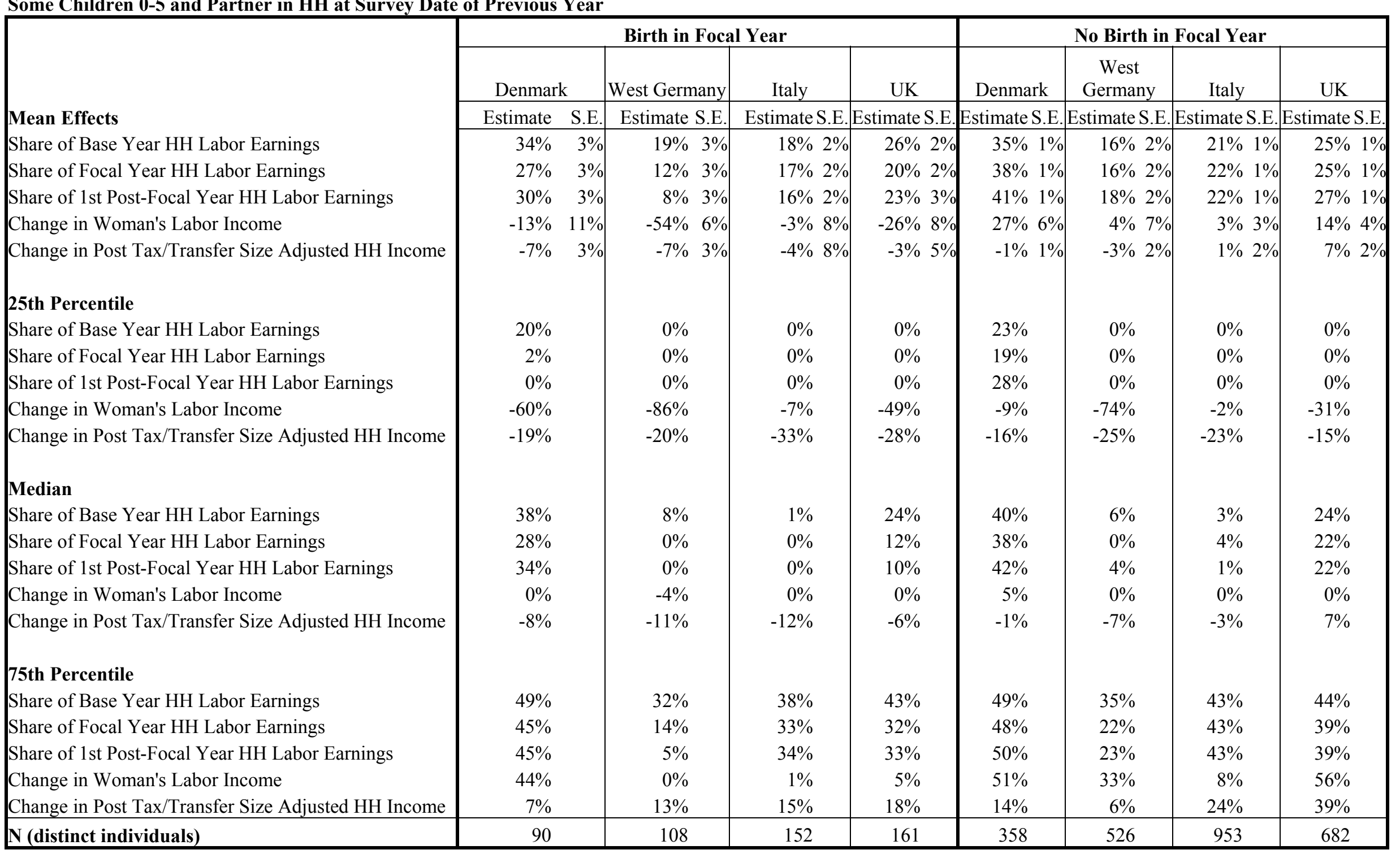


Table 11:

Proportions of Households Paying for Childcare at Survey Time in the Year Following the Focal Year Partner in HH at Survey Date of Previous Year, 1995-1997 Focal Year

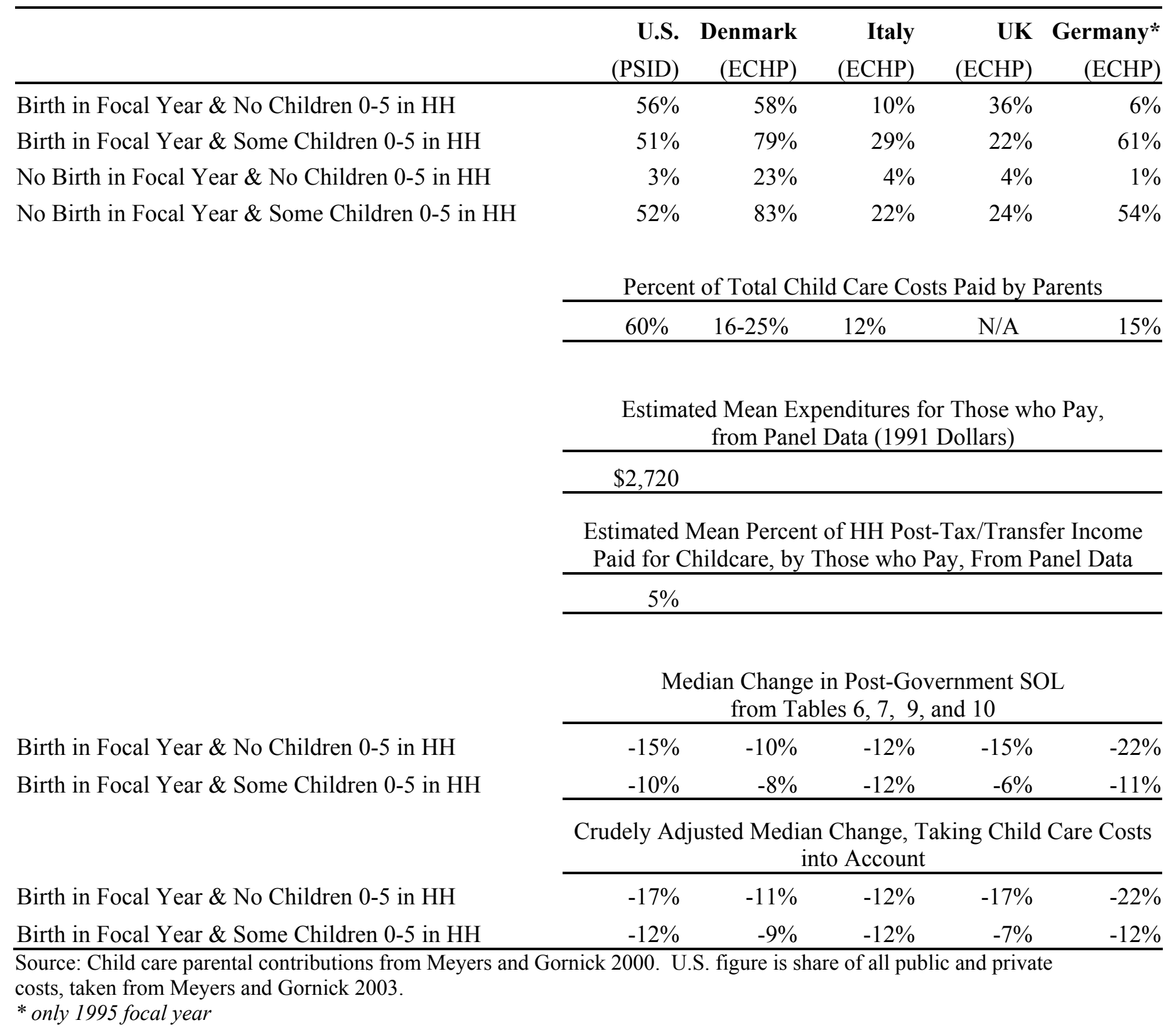


Table 12. A Comparison of the Rank Order of Countries Based on Fertility Rates, Parity Progression Ratios, and Costs of Children Measures

\begin{tabular}{|c|c|c|c|c|c|}
\hline & Denmark & U.S. ${ }^{1}$ & U.K. & Germany & Italy \\
\hline I. FERTILITY RATES & \multicolumn{5}{|c|}{ Countries Ranked from High to Low } \\
\hline Unadjusted TFR 1985-89 & 3 & 2 & 1 & 4 & 5 \\
\hline Adjusted TFR 1985-89 & 3 & 2 & 1 & 5 & 3 \\
\hline Unadjusted TFR 1990’s & 3 & 2 & 1 & 4 & 5 \\
\hline Adjusted TFR 1990’s & 3 & 2 & 1 & $\sim 4$ & $\sim 4$ \\
\hline $\begin{array}{l}\text { Tempo-Adjusted PPR at Parity } \\
0 \text { (most recent data) }\end{array}$ & 1 & 2 & 3 & 5 & 4 \\
\hline $\begin{array}{l}\text { Tempo-Adjusted PPR at Parity } \\
1 \text { (most recent data) }\end{array}$ & 4 & 3 & 1 & 2 & 5 \\
\hline II. COSTS OF CHILDREN & \multicolumn{5}{|c|}{ Countries Ranked from Low to High } \\
\hline \multicolumn{6}{|l|}{ II.a. $\underline{\text { Non-Monetary Costs }}$} \\
\hline $\begin{array}{l}\text { Time Demands, Full Time } \\
\text { Female Workers }\end{array}$ & 1 & 2 & 5 & 3 & 4 \\
\hline Time Demands, Housewives & 2 & 1 & 3 & 4 & 5 \\
\hline $\begin{array}{l}\text { Perceived Conflict between } \\
\text { Work and Childrearing }\end{array}$ & $(1)^{2}$ & 2 & 2 & 4 & 4 \\
\hline \multicolumn{6}{|l|}{$\begin{array}{l}\text { II. b. Short-Term Impact on } \\
\text { Household SOL }\end{array}$} \\
\hline $\begin{array}{l}\text { Median } 3 y r \text { change in SOL, } \\
\text { NO young children in } \mathrm{HH}\end{array}$ & 1 & $\sim 2(3)$ & $\sim 2(3)$ & 5 & $\sim 2(2)$ \\
\hline $\begin{array}{l}\text { Median 3yr change in SOL, } \\
\text { young children in } \mathrm{HH}\end{array}$ & $\sim 1(2)$ & $\sim 3(3)$ & $\sim 1(1)$ & $\sim 3(4)$ & $\sim 3(5)$ \\
\hline $\begin{array}{l}\text { Median } 3 y r \text { change in SOL, } \\
\text { NO young children in } \mathrm{HH} \text {, } \\
\text { including childcare costs }\end{array}$ & $\sim 1(1)$ & 3 & 3 & 5 & $\sim 1(2)$ \\
\hline $\begin{array}{l}\text { Median } 3 y r \text { change in SOL, } \\
\text { young children in } \mathrm{HH}, \\
\text { including childcare costs }\end{array}$ & 2 & 3 & 1 & 3 & 3 \\
\hline
\end{tabular}

Note: Numbers in parentheses are used to indicate approximate ties when numerical differences between countries are small.

\footnotetext{
${ }^{1}$ Fertility ranking is based on rates for the non-Hispanic white population.

${ }^{2}$ Based on the ISSP data for Norway and Sweden.
} 